\title{
Dead Infants, Cruel Mothers, and Heroic Popes: The Visual Rhetoric of Foundling Care at the Hospital of Santo Spirito, Rome
}

\author{
by Diana Bullen Presciutti
}

\begin{abstract}
The fresco cycle painted at the behest of Pope Sixtus IV in the late 1470s in the main ward of the hospital of Santo Spirito in Rome comprises an extended pictorial biography of Sixtus, prefaced by scenes representing the legendary foundation of the hospital by his predecessor Innocent III. The legend, which tells how Innocent established Santo Spirito as a foundling hospital in response to the discovery of victims of infanticide in the Tiber River, positions the pope as the savior of the city's unwanted children. This article elucidates how the construction and renovatio of the hospital is presented in the cycle as a generative product of papal will, with the care of foundlings situated as an integral part of the image of the pope as both Father of the Church and restorer of past glory to the city of Rome. While the frescoes engage with both widespread conventions for representing infanticide and commonplace notions of the social value of caring for abandoned children, I demonstrate that the ideologically potent visual rhetoric offoundling care was also flexible, and could be adapted to meet the specific needs of a particular institutional and patronal context.
\end{abstract}

\section{INTRODUCTION}

T $\mathrm{n}$ the late 1470s, just as his rebuilding of the Hospital of Santo Spirito in 1 Rome was nearing completion, Pope Sixtus IV (r. 1471-84) commissioned

"Please see the online version of this article for color illustrations.

I would like to thank the Department of the History of Art and the Institute for the Humanities at the University of Michigan, the Andrew W. Mellon Foundation, the American Council of Learned Societies, and the Humanities Research Center at Rice University for their support during the course of researching and writing this article. I am most grateful to Angela Ho, Megan Holmes, Katie Hornstein, Eunice Howe, Julie Hruby, Diane Owen Hughes, Timothy McCall, Kirsten Olds, Sasha Pfau, Olivia Poska, Ivano Presciutti, Betsy Sears, Pat Simons, Louise Stein, and the anonymous readers at Renaissance Quarterly for their suggestions and assistance. A portion of this research was presented at the Beholding Violence symposium organized by Allie Terry-Fritsch and Erin Labbie at Bowling Green State University in March of 2008. I would also like to acknowledge the archivists, librarians, and staff at the Biblioteca Apostolica Vaticana, the Archivio Segreto Vaticano, the Archivio di Stato in Rome, and the Kunsthistorisches Institut in Florence, as well as Mélanie Matthey, the staff of Giubilarte, and Marco Fiorilla of the Biblioteca Lancisiana. Thank you to Erika Suffern and Timothy Krause for valuable comments and suggestions. All translations are the author's except where otherwise noted. 


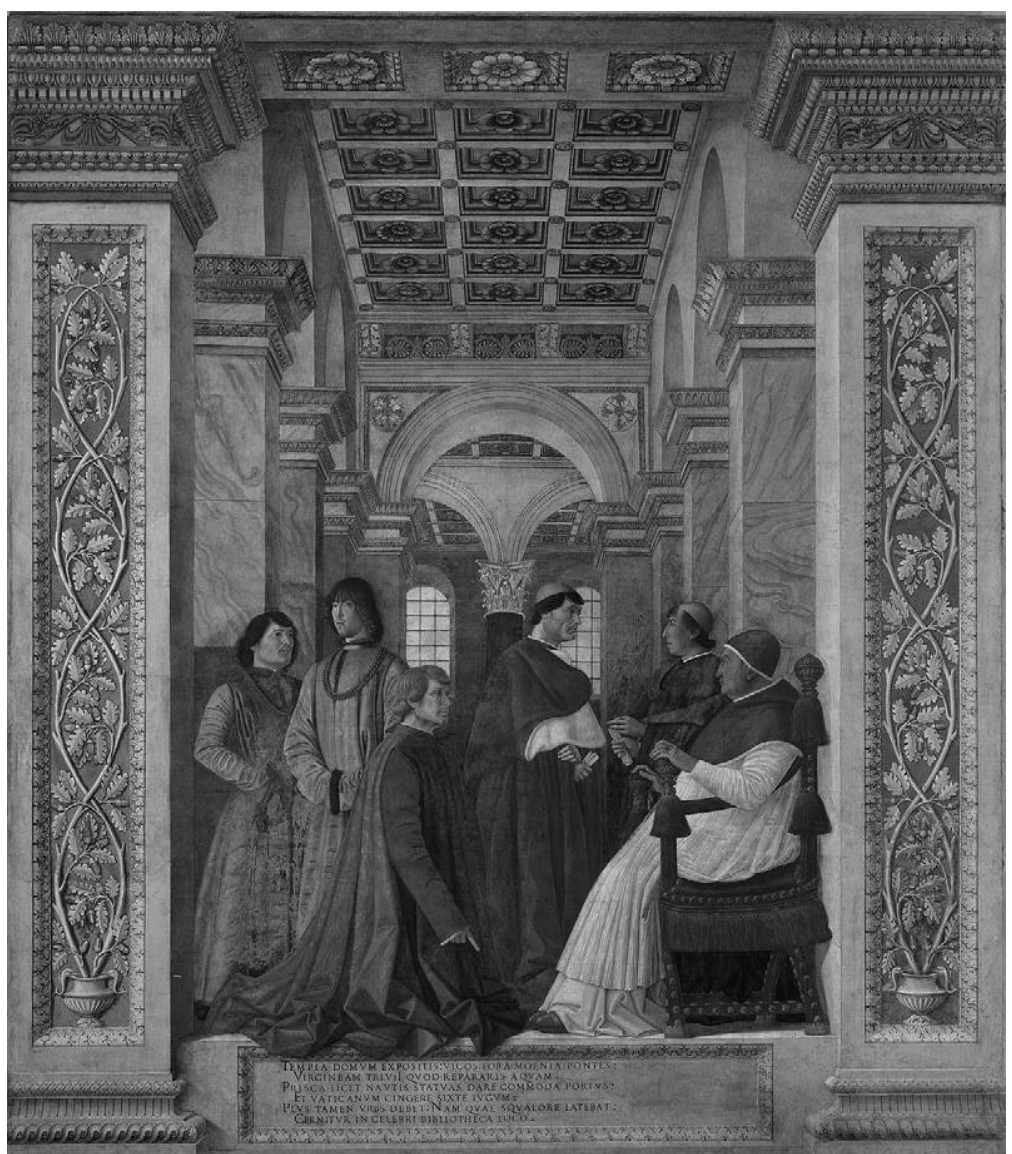

FIGURE 1. Melozzo da Forlì, Sixtus IV, His Nephews and Platina, fresco transferred onto canvas, late 1470s. Vatican City, Pinacoteca Vaticana. C SCALA/Art Resource, NY.

Melozzo da Forlì to paint his portrait (fig. 1). ${ }^{1}$ In the finished fresco, originally located on the north wall of the Sala Latina in the Vatican Library, the pope appears seated on his throne, accompanied by four of his nephews and the recently appointed Vatican librarian, Platina. The fresco also includes an inscription composed by Platina extolling Sixtus's accomplishments: "[the city of Rome owes to you] Temples, a house for foundlings; streets, piazze, walls,

${ }^{1}$ The fresco is undocumented and has been dated as early as 1474 and as late as 1481 , the year Melozzo departed Rome. For a discussion of the fresco in the context of both the Sistine court and the hospital of Santo Spirito, along with an updated summary of the literature, see Howe, 2005, 60-71. 
bridges; the Aqua Vergine of the Trivio that you restored; you established the harboring of sailors, [their] ancient advantage; and the [walls encircling] the Vatican, Sixtus: greater still the city owes [to you]: the library, which was hidden in squalor but now is distinguished in [this] honored place."

The fresco and its inscription served in many ways as a condensed articulation of Sixtus's desired legacy, a carefully assembled portrait of those aspects of his persona and pontificate with which he most wanted to be associated in perpetuity. The itemized inscription places the focus squarely on his restoration of the urban infrastructure of Rome, thereby constructing the pope as a new Augustus. Second among the enumerated projects is the hospital of Santo Spirito, referred to as a domum expositis, a house for foundlings. Santo Spirito, however, was an established multifunctional hospital, dedicated to the care of the sick poor, impoverished nobles, pregnant women, and pilgrims, in addition to abandoned children. Sixtus rebuilt Santo Spirito to serve the multiple constituencies that historically had been cared for by the nearly 300-year-old hospital. However, in the inscription and elsewhere he promoted his intervention as particularly focused on solving the social problem of infant abandonment, identified throughout Italy as a critical issue in the fifteenth century. ${ }^{3}$ The disjuncture between the characterization of Santo Spirito as a foundling hospital in the inscription and the diversity of its actual institutional functions highlights the central place accorded to foundlings in the image of ideal papal rule fashioned by Sixtus and his supporters.

The image of the pope as both restorer of Rome's infrastructure and savior of the city's unwanted children was further elaborated in a fresco cycle commissioned by Sixtus for the main ward of Santo Spirito in the same years as the group portrait in the Vatican Library. The cycle includes representations of the foundation legend of Santo Spirito, the building of the hospital by Innocent III (r. 1198-1216), its reconstruction by Sixtus, and the ideal care of foundlings under Sixtus's tutelage. Whereas the Vatican Library portrait was condensed and carefully edited, with the frescoes in Santo Spirito, Sixtus opted for a different strategy for a visual encomium, one that emphasized clear, legible exposition and reiteration. At the center of

${ }^{2}$ TEMPLA DOMVM EXPOSITIS: VICOS FORA MOENIA PONTES: / VIRGINEAM TRIVII QVOD REPARARIS AQVAM / PRISCA LICET NAVTIS STATVAS DARE COMMODA PORTVS: / ET VATICANVM CINGERE SIXTE IVGVM: / PLVS TAMEN VRBS DEBET: NAM QVAE SQVALORE LATEBAT: / CERNITVR IN CELEBRI BIBLIOTHECA LOCO.

${ }^{3}$ The bibliography on infant abandonment in fifteenth-century Italy is extensive. See, among others, Sandri; Gavitt; Albini, 131-83; Hunecke; Takahashi; Bianchi, esp. 9-32; Presciutti, 2008. 
the image of papal authority shaped by the cycle was the abandoned child, the prototypical beneficiary of the charitable largesse of both Sixtus IV and the institution of the papacy. This article will elucidate how, in a manner analogous to the inscription in the Vatican Library fresco, the cycle derives its semantic potency from three interconnected sources: the well-established political authority of papal rebuilding, the newly configured ideological power of foundling care, and the rhetorical efficacy of inventorial repetition. Tensions arise in the marshaling of these diverse forces, however, as the frescoes mediate between two often conflicting obligations: the pictorial attention to preexisting traditions and predecessors required of renovatio, and the more focused visual exaltation of Sixtus alone.

\section{Sixtus IV and the Hospital of Santo Spirito}

Today Benito Mussolini's via della Conciliazione obliges pedestrians approaching the Vatican Borgo from the east to confront immediately the massive façade of New St. Peter's, compressing the space between the basilica and the river at the expense of the surrounding structures. ${ }^{4}$ In the late fifteenth century, however, a visitor to the Borgo would have faced, not the soon-to-be-demolished Constantinian basilica, but instead the east façade of the hospital of Santo Spirito to the south and the mighty bulk of the Castel Sant'Angelo to the north, with a desultory collection of medieval buildings between them. These two structures, representing the charitable munificence and military might of the papacy, respectively, served as bookends for the neighborhood of the Borgo, shaping perceptions of both the zone as a whole and the papal institution at its core.

Santo Spirito also played a crucial role in the evolving development of the Vatican Borgo as a locus of political power in the urban theater of fifteenth-century Rome. As Carol William Westfall and others have demonstrated, the relocation of the papal residence from St. John Lateran to the vicinity of St. Peter's had profound consequences for the urban dynamics of the city. ${ }^{5}$ The move to the west side of the Tiber worked to marginalize the magnate centers of political power (the Capitoline), cultic devotion (the Lateran), and institutional charity (San Salvatore). Taking up where his predecessors left off, Sixtus reaffirmed this new Tiber-centric organization of the city through building projects: the Sistine Chapel, the Vatican Library, the churches of Santa Maria del Popolo and Santa Maria della Pace, the Ponte Sisto, as well as the hospital of Santo Spirito.

${ }^{4}$ On the via della Conciliazione, see, most recently, Kirk.

${ }^{5}$ Westfall. See also Magnuson; Burroughs. 


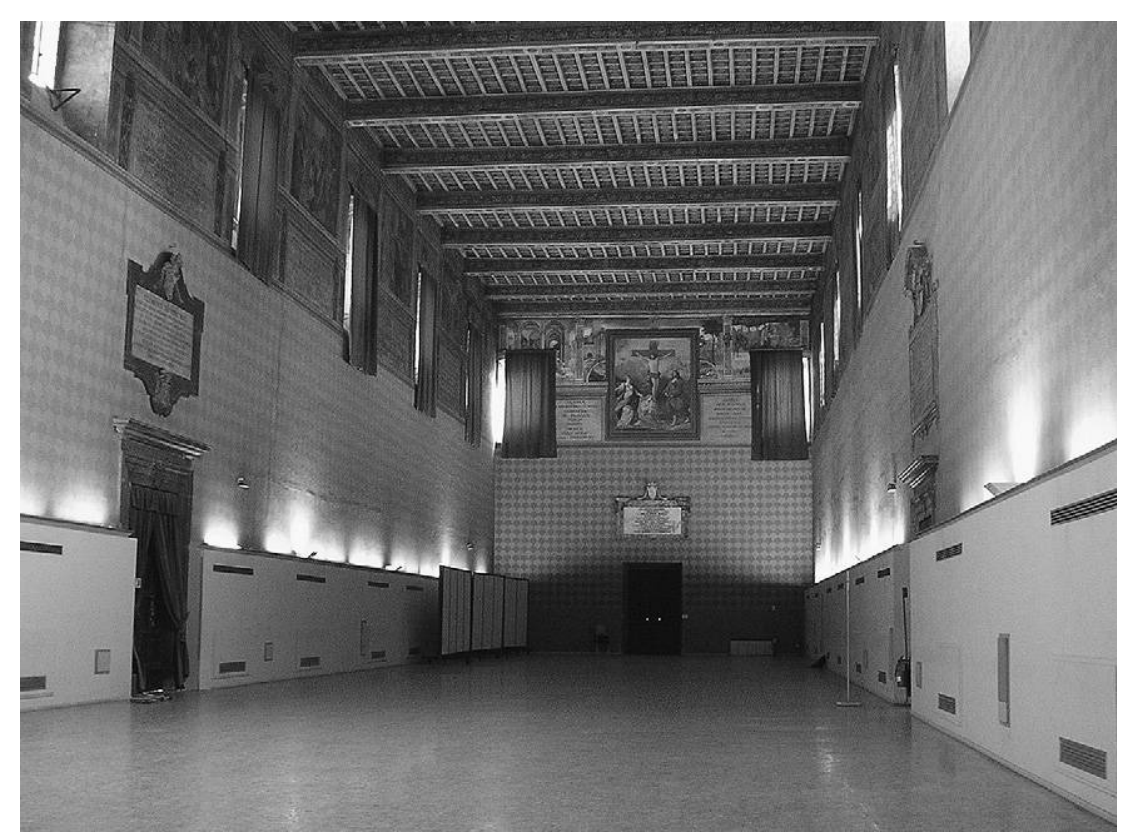

FIGURE 2. East ward, Corsia Sistina, Ospedale di Santo Spirito in Sassia, Rome. Author's photograph.

The rebuilding of Santo Spirito was the most ambitious of the projects that Pope Sixtus initiated for the Jubilee Year of $1475 .{ }^{6}$ From its inception between 1198 and 1201, at the behest of Pope Innocent III, Santo Spirito had been conceived of as the "the hospital of the popes," and the fortunes of the institution, like those of the city itself, had ebbed and flowed with that of the papacy during the turbulent fourteenth century. ${ }^{7}$ By the early fifteenth century, the hospital was reported to be in shambles, necessitating an almost complete renovation of the existing edifice. Although the bell tower and other structural elements survived Sixtus's reconstruction of the hospital in the early $1470 \mathrm{~s}$, much of the institution was rebuilt ex novo. Still extant from this fifteenth-century rebuilding campaign are the loggiated courtyards for the foundlings and the nobles, and the monumental ward for pilgrims and the sick, the Corsia Sistina (fig. 2).

${ }^{6}$ For the history of the hospital and its rebuilding during the pontificate of Sixtus IV, see Canezza; De Angelis, 1960-62, 2:97-306, 320-49; Howe, 1978 and 2005; Colonna, 19-58.

${ }^{7}$ On the foundation of the hospital by Innocent III and the relationship between the Hospital of Santo Spirito and the hospitaller Order of the Holy Spirit, see, most recently, Drossbach, 2005. 
Sixtus used Santo Spirito as a theater for the crafting of an image of himself as the ideal pope, and his family, the della Rovere of Liguria, as a quasi-princely dynasty. The oak-tree stemma of the della Rovere remains a pervasive fixture within the hospital complex to this day. The phrase SIXTVS IV FUNDAVIT also appears on windows and doorframes throughout the institution. The most elaborate visual exaltation of Sixtus was reserved, however, for the fresco cycle the pope had painted in the Corsia Sistina. Like the more famous Pellegrinaio in the Scala hospital in Siena, the ward primarily housed pilgrims and sick, poor men who were neither disabled enough to be placed in the injured ward nor sufficiently well-born to qualify for accommodation in the nobles' quarters. The Corsia was open to some level of public access, which differentiated the ward from other areas of the hospital, such as the palace for wet nurses and their charges, where entry was more restricted. ${ }^{8}$ Thus the frescoes would have been seen by different categories of viewers. Patients, attendants, pilgrims, doctors, surgeons, visiting sovereigns, writers, and religious, among others, would have passed through the space, many on a regular basis, allowing the extensive painted embellishment to communicate multiple messages to a range of spectators. ${ }^{9}$

The fresco cycle (fig. 3), likely painted between 1476 and 1478, is comprised primarily of narrative sequences: seven scenes depicting the legendary foundation of the hospital by Pope Innocent III, beginning on the east wall of the ward, are followed by thirty-four episodes from the life of Sixtus IV. ${ }^{10}$ The space is dominated by the Sistine scenes, which fill the west, north, and most of the south walls. Roughly commensurate in size to the narrative frescoes in the cycle are the inscription panels, which appear below each composition. The inscriptions were later replaced, but the original

${ }^{8}$ See Howe, 1978, 56-68; Howe, 2000, esp. 245-50; Esposito, esp. 203.

${ }^{9}$ On the artistic decoration of Renaissance hospital wards, see Henderson, 147-85. In contrast to the mid-fifteenth-century frescoes in the Ospedale della Scala in Siena, which comprise scenes from the history of the hospital and representations of institutional activities, the only recipients of hospital charity depicted in the Santo Spirito cycle are foundlings and, in one scene, nobles. On the Sienese cycle, see, most recently, Costa and Ponticelli.

${ }^{10} \mathrm{~A}$ lack of documentation has inhibited attempts to precisely date the frescoes. However, based on the completion of the roof in 1476 and the opening of the hospital in 1478, Howe convincingly dates the cycle to 1476-78. Between 1478 and 1484 there was a hiatus, she argues, followed by the addition of three more scenes in 1484, after the death of Sixtus: see Howe, 2005, 110. Five additional scenes, representing episodes from Sixtus's pontificate that postdate the 1470 s decorative campaign, were added to the east side of the north wall in 1599. For the 1599 contract, see Archivio di Stato di Roma (hereafter ASR), Ospedale di Santo Spirito (hereafter OSS), 273, fols. $15^{\mathrm{r}}-17^{\mathrm{v}}$. 


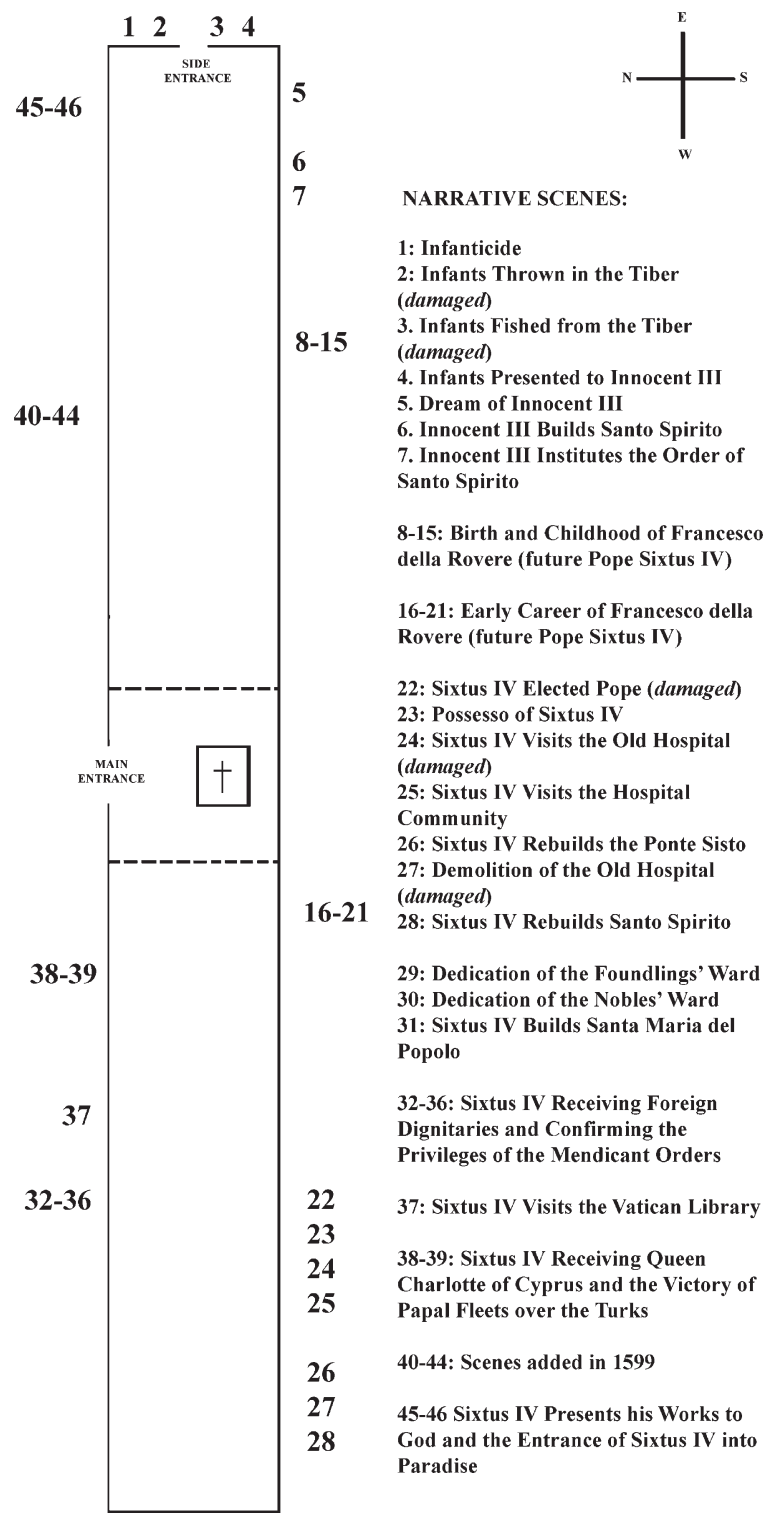

313029

FIGURE 3. Plan of the Corsia Sistina, Ospedale di Santo Spirito in Sassia, Rome. Author's diagram. 
fifteenth-century texts are recorded in manuscript sources. ${ }^{11}$ The overall organization of the cycle and many of the fifteenth-century inscriptions have been credited to Platina, who, in addition to his duties as Vatican librarian, seems to have been entrusted with crafting a public image for the della Rovere pope. $^{12}$

Due primarily to the workshop production of the cycle and its poor physical condition, ${ }^{13}$ scholars have focused on the iconographic content of the frescoes, the textual sources for the inscriptions, and the place of the cycle among the many artistic projects of Sixtus IV. ${ }^{14}$ The frescoes have largely been presented as secondary to the inscriptions, as literal illustrations of texts rather than as partners in the production of meaning. Yet the process of creating and viewing the frescoes in the Corsia Sistina played a constitutive role in the generation of new visual rhetorics of infanticide, institutional charity, and papal authority, such as the reimagining of Sixtus's rebuilt Santo Spirito as a domum expositis. The present study demonstrates how a widespread discursive convention — the claim that building a foundling hospital prevented infanticide - could be productively tailored to meet the needs of a particular institutional and patronal context. The specter of infanticide and the patriarchal nature of building a refuge for abandoned children were tropes found in textual and visual sources connected with

\footnotetext{
${ }^{11}$ The inscriptions currently on view in the Corsia Sistina were installed in 1642 . Three manuscripts in the Biblioteca Apostolica Vaticana comprise the primary sources from which several scholars over the course of the past two centuries have compiled differing versions of the original Quattrocento inscriptions: Barb. lat. 2040 (hereafter MS Barb), Chigi I-V-167 (hereafter MS Chigi), and Urb. Lat. 1023 (hereafter MS Urb). The only source for a second set of inscriptions, installed in 1599, is Forcella, 6:417-40. Forcella refers to a now-lost register from the hospital archives as his source. Although the inscriptions from the 1599 intervention tend to be, in general, more verbose than the fifteenth-century versions, the content remains largely unchanged through the various iterations.

${ }^{12}$ On Platina's role at Santo Spirito, see Howe, 2005, 78-79. The fifteenth-century inscriptions for the Sistine scenes have their origins in both the biography of Sixtus written by Platina and the Lucubraciunculae Tiburtinae of the Englishman Robert Flemmyng. On Platina's Life of Sixtus $I V$, see Howe, 2005, esp. 19-40. For the text of the Lucubraciunculae Tiburtinae, see Pacifici. On Flemmyng and his relationship to Sixtus and Platina, see Howe, 2005, 79-85.

${ }^{13}$ On the condition of the frescoes, see Cardilli, 2002. Although many attributions have been suggested over the years, archival evidence to identify the artists has not emerged. For a summary of the various attributions of the frescoes, see Howe, 2005, 106-13.

${ }^{14}$ The most substantial treatment of the frescoes has been conducted by Eunice Howe. See Howe, 1978 and 2000; Howe, 2005, esp. 73-99. Howe has focused primarily on the Sistine scenes, giving particular attention to the identification and analysis of textual sources and to the relationship between the cycle and the humanist ambit of the Sistine papal court. On the cycle, see also Brockhaus; De Angelis, 1961; Miglio. On the artistic patronage of Sixtus, see, among others, Sisto IV.
} 


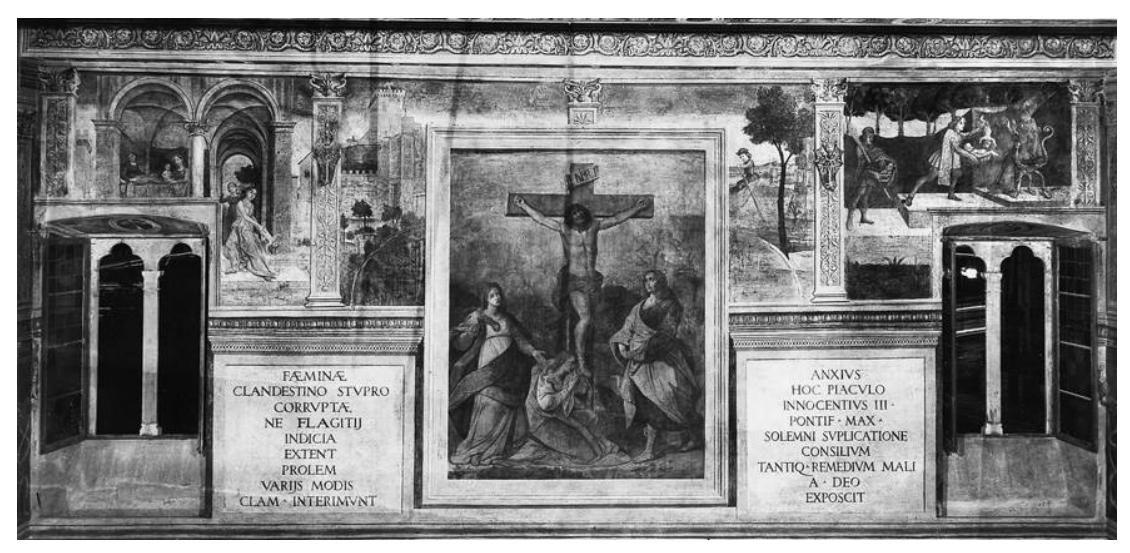

FIGURE 4. East wall, Corsia Sistina, Ospedale di Santo Spirito in Sassia, Rome. (C) Eunice D. Howe.

hospitals for foundlings throughout Italy. The visual rhetoric of foundling care that evolved in the Corsia Sistina, however, with its cruel mothers and heroic popes, was specific to the urban context of Sistine Rome.

\section{3. "Their Infants Shall Be Dashed to Pieces"}

The cycle begins on the north side of the east wall of the Corsia Sistina (fig. 4). The first fresco, Infanticide (fig. 5), is divided into two parts. To the left, in a well-appointed bedchamber, a woman rests after the labors of childbirth (fig. 6). A female attendant looks after her newborn child. The scene constructs the birth chamber as a tranquil space tended by women and populated by resting mothers and female attendants. ${ }^{15}$ Moving outside the bedchamber, however, the serene atmosphere abruptly shifts to one of chaotic violence. This division is thematized by the compositional structure of the fresco, as the horizontal lines that dominate the bedchamber give way to a series of diagonals in the outdoor scene. A woman wearing a voluminous yellow dress moves outward toward the picture plane, followed by another figure, who raises her arms in alarm (fig. 7). In the hands of the first woman is a profusely bleeding, and apparently dead, infant (fig. 8). The newborn's head has received a heavy blow and blood pours out from it, collecting in a bright red pool on the pavement below.

\footnotetext{
${ }^{15}$ This formulation follows conventional representations of sacred birth scenes, such as the contemporary fresco of the birth of John the Baptist in the church of San Giovanni Evangelista in Tivoli, and likely also related closely to fifteenth-century middle- and upper-class social practices.
} 


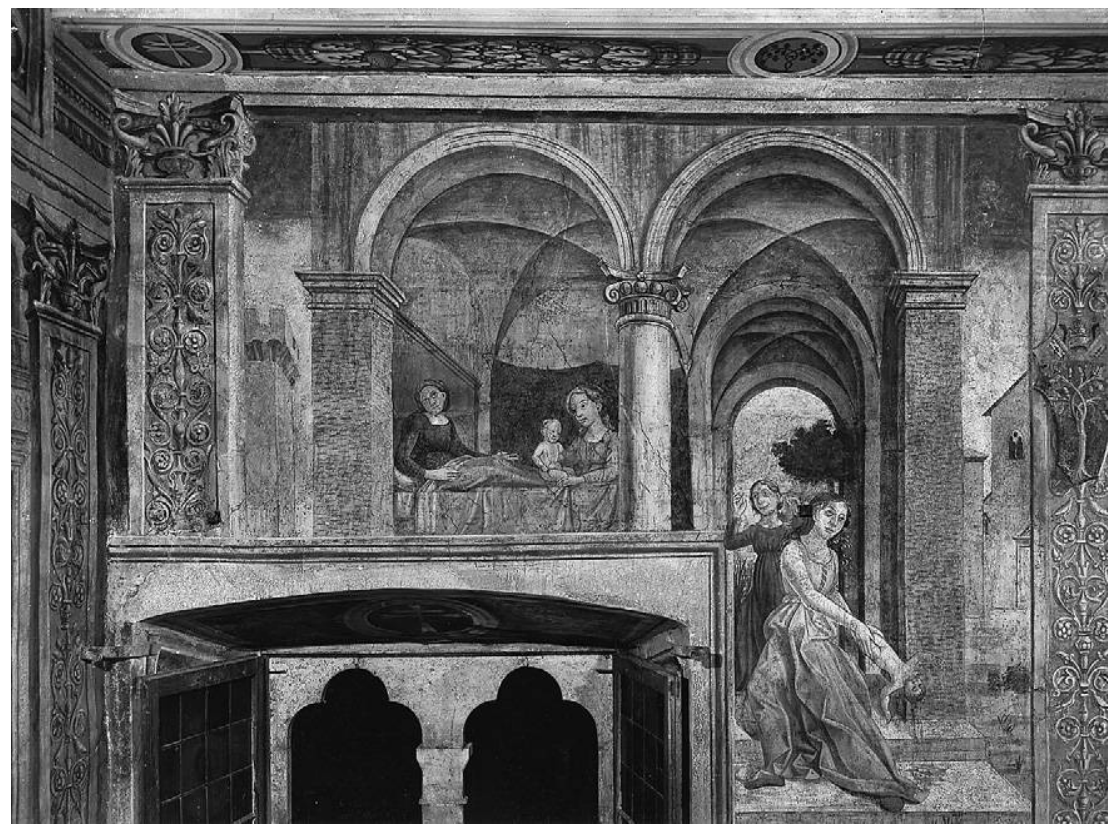

FIGURE 5. Unknown artists, Infanticide, late 1470s. East wall, Corsia Sistina, Ospedale di Santo Spirito in Sassia, Rome. (c) Eunice D. Howe.

This image of infanticide marks the beginning of the legendary foundation of Santo Spirito by Pope Innocent III, a story that combined elements of historical fact with miraculous visions, heavenly intervention, and ideologically motivated omissions, adjustments, and inventions. ${ }^{16}$ The earliest surviving account of this foundation legend, the Chronik of Jacob Twinger of Königshofen, dates to the late fourteenth century, almost 200 years after the events of the legend were purported to have taken place. ${ }^{17}$ According to the story, Roman children were being killed and then tossed into the Tiber by their mothers, who sought to hide the evidence of their

${ }^{16}$ In general, the Innocentine scenes have not received the critical attention paid to the Sistine narrative. For the most in-depth analysis of the foundation legend, see Walter, 1985, on textual and visual representations of infanticide in institutional foundation legends and their relationship to ecclesiastical and secular attitudes toward child-killing. Ibid. explores the origins of the foundation legend, adducing other versions and related visual imagery. See also Walter, 2006. The Innocentine frescoes are also discussed in Howe, 1978, 200-07; Guerrini; Howe, 2005, 123.

${ }^{17}$ The description of the foundation legend is found in a section of Twinger's Chronik on the pontificate of Innocent. For the text, see Hegel, 2:569. For Twinger's biography and possible connections to the Order of Santo Spirito, see Walter, 1985, 824-25. 


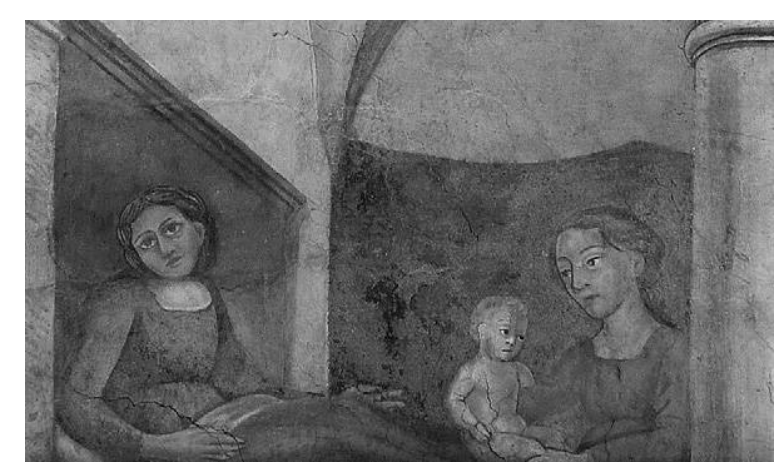

FIGURE 6. Unknown artists, Infanticide (detail), late 1470s. East wall, Corsia Sistina, Ospedale di Santo Spirito in Sassia, Rome. Author's photograph.

illicit sexual activity. After being presented with the corpses of these infants by his fishermen, who had caught them in their nets, Innocent III resolved to found a hospital for abandoned children, so that these "evil" (böse) women would have the option to conceal their shame through the anonymous abandonment of their unwanted offspring. ${ }^{18}$ The version of the story on the east wall of the Corsia Sistina begins with the infanticide and ends with the presentation to Innocent III of the dead infants fished from the Tiber. The central two scenes on the wall have been largely obscured by the later addition of a Crucifixion fresco. ${ }^{19}$ According to the fifteenth-century inscriptions, these scenes depicted women throwing their children into the Tiber and the discovery of the bodies by the pope's fishermen.

This retelling of the events leading up to the foundation of Santo Spirito is belied by papal proclamations from the time, which clearly indicate that the hospital was established as a multifunctional charitable institution, not solely as a foundling hospital. ${ }^{20}$ In Inter opera pietatis, the bull of 1204 confirming the foundation of the hospital, Innocent III framed the mission of

\footnotetext{
${ }^{18}$ Hegel, 2:569.
}

${ }^{19}$ The date of this addition is unknown. See Howe, 1978, 145n40. De Angelis, 1961, 130-31, without explanation dates the Crucifixion fresco to 1750 .

${ }^{20}$ With Hic praecipue Praelati Ecclesiarum (1198), Innocent conferred on Guy de Montpellier, the French founder of the hospital Order of Santo Spirito (Saint-Esprit), the right to establish hospices and to build oratories and cemeteries. Later that year, with Religiosam vitam eligentibus, Innocent confirmed the order, according it and its hospitals the protection of the Vatican and increased privileges. In 1201, with Cupientes proplurimis, Innocent endowed the hospital and church of Santo Spirito in Sassia at Rome. Finally, the foundation of the Roman hospital was confirmed in Inter opera pietatis of 1204, in which Innocent instituted the Frati of Santo Spirito and defined the obligations and authority of their leader. For transcriptions of all four bulls, see De Angelis, 1960-62, 1:375-84. 


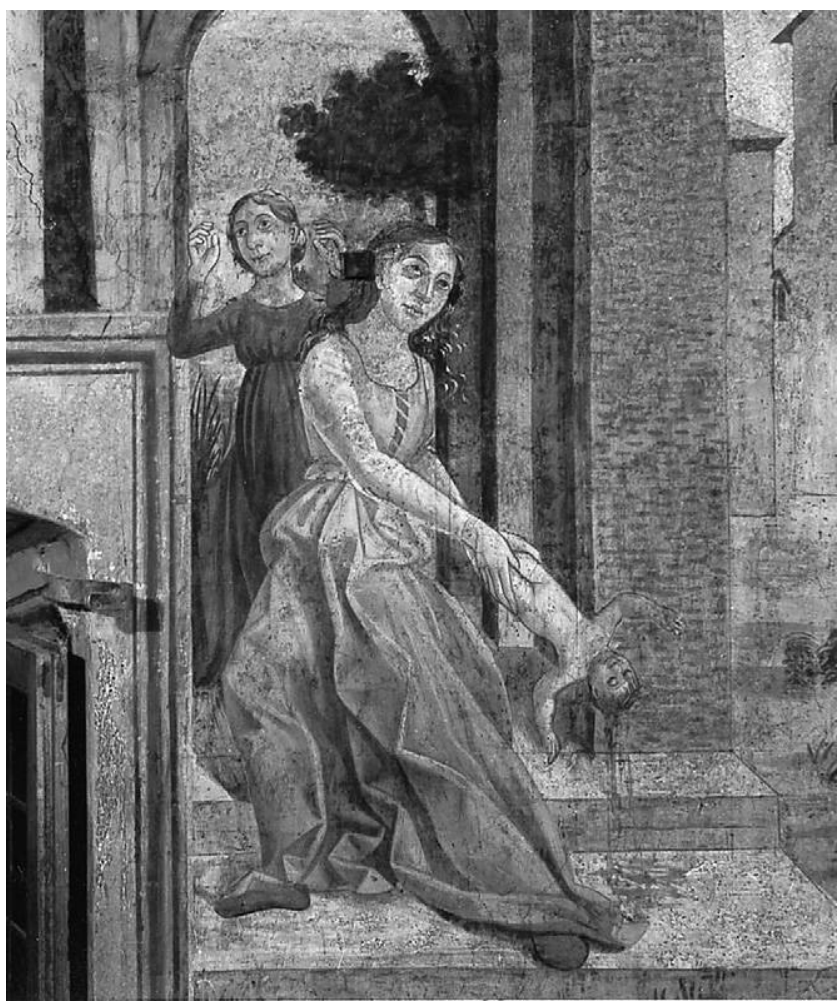

FIGURE 7. Unknown artists, Infanticide (detail), late 1470s. East wall, Corsia Sistina, Ospedale di Santo Spirito in Sassia, Rome. (C) Eunice D. Howe.

Santo Spirito around the biblical works of mercy and made no reference to the care of foundlings. The first bull even to mention abandoned children at Santo Spirito was issued by Nicholas IV in 1291, almost a full century after the foundation of the hospital by Innocent. ${ }^{21}$ By the fifteenth century, sporadic references indicate that foundlings were among those regularly admitted to Santo Spirito, but it was not until the pontificate of Sixtus IV that this activity became privileged in the rhetorical descriptions of the hospital. ${ }^{22}$

${ }^{21}$ The bull of Nicholas IV, Charitatis opera (1291), is in ASR, OSS, 1, fol. $42^{\mathrm{r}-\mathrm{v}}$. See also Walter, 1985, 835.

${ }^{22}$ Walter, 1985, 836, argues that the increased frequency with which foundlings are mentioned in the papal bulls suggests that a larger proportion of hospital operations was dedicated to their maintenance. However, the language with which these documents describe hospital functions is extremely formulaic, and changes in the formulas should be seen as an indicator of a shift in discourse, not necessarily as a concomitant change in hospital administration or operations. 


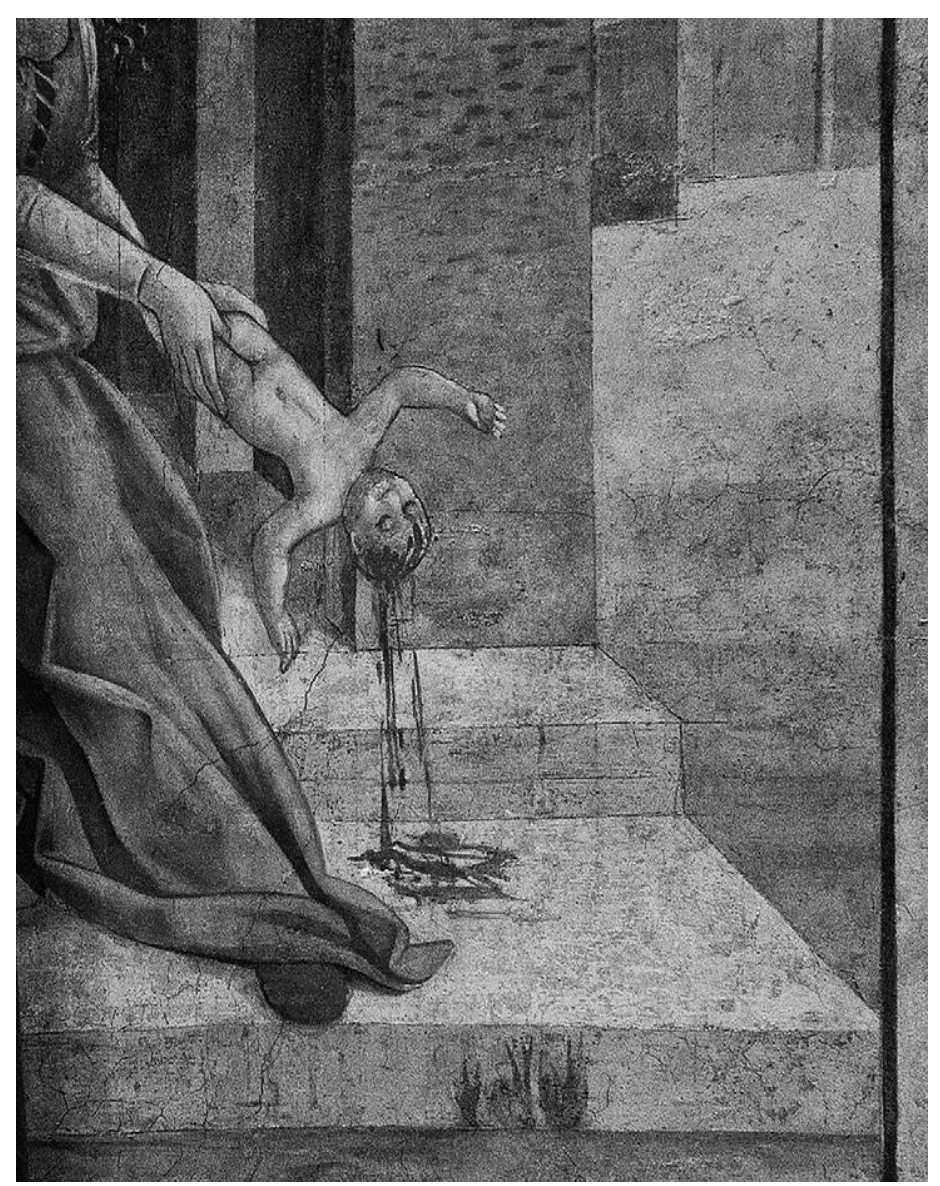

FIGURE 8. Unknown artists, Infanticide (detail), late 1470s. East wall, Corsia Sistina, Ospedale di Santo Spirito in Sassia, Rome. Author's photograph.

The decision to preface the pictorial biography of Sixtus IV on the walls of the Corsia Sistina with the foundation legend of Santo Spirito testifies to the ideological importance attached to foundling hospitals in fifteenthcentury Italy, particularly as an institutional antidote to infanticide. ${ }^{23}$ Although the rhetorical tie between the institutional care of foundlings and infanticide is documented in a handful of records from as early as 1294, by the second half of the fifteenth century this association had become

${ }^{23}$ On the historical reality of infanticide in Renaissance Italy, see Trexler; Walter, 1985, 870-74. 
a discursive commonplace. ${ }^{24}$ For example, the act of foundation for the foundling hospital in Pavia, which was processed by the notary Lodovico de Legge on 21 April 1479, contemporary with the execution of the frescoes in the Corsia Sistina, states that the hospital was needed "in order to prevent the poor esposti, or bastardelli, from dying because of the little or no care that is taken of them, not only with respect to their bodies but also their souls; as even recently multitudes of them have been found in various places around the city of Pavia, others devoured or lacerated by dogs and by hogs, and others dead from the cold chiefly during the winter season, and that many even, it is believed, are secretly killed by their mothers." ${ }^{25}$ Similarly, a provvisione of 1484 made to the government of Florence requesting aid for the Innocenti foundling hospital praises the institution as a remedy for infanticide: "consider how laudable a thing it is to accept in such a place so many poor creatures abandoned without baptism at the moment of their birth by their parents. Such poor [infants] would be found dead, often in rivers and sewers and ditches, if that place had not been constituted as a receptacle for them." 26

In the Corsia Sistina fresco, the threat of child-killing is made visually explicit. The red blood flowing from the head of the infant serves to catch the eye of the viewer standing forty feet below, drawing attention

${ }^{24} \mathrm{~A}$ petition dated 1294 concerning the San Gallo hospital in Florence claims that the institution was necessary in order "to avoid the many crimes which are committed against infants" ("ad evictandum multa crimina qu[a]e de infantibus commictebantur"): Archivio di Stato di Firenze (hereafter ASF), Provvisioni Registri 4 (19 May 1294), fol. $8^{\mathrm{r}}$. The document is published in Passerini, 935-37. Similarly, the bull confirming the foundation of the Misericordia hospital in Perugia, dated 1305, specifically imputes to the hospital the role of savior of imperiled infants: Atto di fondazione, 7, 9. Before the hospital was established, the document claims, "infants had been discovered suffocated in foul places" ("infantuli reperiebantur in locis turpibus suffocati"): ibid., 7. In the new Misericordia hospital, by contrast, these infants, along with pilgrims and the poor, would be welcomed and nourished.

${ }^{25}$ Magenta, appendix, 13: "onde impedire che i poveri esposti, o bastardelli non periscano a cagione della poca o nessuna cura che si ha di essi, non solo rispetto al corpo, ma ben anche alle loro anime, come pur di recente molti, e molti di essi furono trovati in diversi luoghi di questa città di Pavia, altri divorati o lacerati dai cani e dai porci, ed altri morti dal freddo segnatamente nella stagione jemale, e che molti eziandio, come si crede, uccidansi secretamente dalle madri."

${ }^{26}$ ASF, Provvisioni Registri 174 (18 February 1484), fol. 157: "et considerato quanta laudabile opera sia acceptare intalluogo tante mis[er]e creature abandonate nel principio della loro nativita dalorparenti lequali sanza baptesimo spesse volte et pe fiumi et per cloache et fosse sarebbono trovate morte, se non fussi suto talluogho constuito per riceptaculo ditali mis[er]i." Visual representations associated with the Innocenti conflated hospital foundlings with the biblical Holy Innocents, a rhetoric of foundling care related to, but fundamentally distinct from, that developed in the Corsia Sistina fresco cycle. See Presciutti, 2008, 179-223; Presciutti, 2010, 249-51. 
immediately into the violent narrative. The infant's nakedness and the peculiar way the woman grasps the child - head down, by the feet accentuate both the vulnerability of the victim and the perpetrator's callous cruelty. The upside-down position of the child underscores the ways in which the situation has gone horribly awry, creating a vivid contrast with the image of idealized birth and child-tending depicted in the bedchamber. Rather than being held tightly in a protective embrace, the newborn child is brutally attacked and discarded.

The compositional structure of the two-part scene suggests that it forms a continuous narrative, following the brief journey of a single infant from birth to premature death. The resting mother in the bedchamber and the woman who raises her arms in distress are likely meant to be read as the same woman, as they share similar facial features, hairstyles, and dress. The woman holding the bleeding child is more difficult to identify. In the context of the narrative, her laced bodice and simple white underblouse evoke contemporary representations of wet nurses and other birth attendants. ${ }^{27}$ Yet such an identification is challenged by the sumptuousness of her overdress, characterized by brilliant hue and elegant folds. The Latin inscription originally found beneath the fresco, while heightening the dramatic pathos of the scene, further complicates the interpretation of the narrative: "[h]ow in different ways the cruel mothers butcher their offspring, which have come into the light following illicit coitus. ${ }^{28}$ Their infants shall be dashed to pieces before their eyes and no pity shall be taken upon the sucklings of the womb." ${ }^{29}$ The

${ }^{27}$ For example, those found in the Cappella Maggiore of Santa Maria Novella in Florence, painted by Domenico Ghirlandaio in the late 1480 s.

${ }^{28} \mathrm{MS}$ Barb, fol. $80^{\mathrm{v}}$ : "Qualiter ex damnato coitu progenitos, ne in lucem veniant crudeles matres diversimode trucidant." Dating from the 1570 s, MS Barb is a compendium of diverse writings, including inscriptions found in various churches, copies of letters, poetry, and orations. As this is the most complete and reliable of the transcriptions, I use this source for most of the inscriptions quoted in this article.

${ }^{29}$ MS Chigi, fol. 175" : "Infantes eor[um] allidentur in oculis eor[um] et lactantibus miserebuntur et sup[er] $\mathrm{p}[\mathrm{ro}] \mathrm{p}[\mathrm{ri}]$ os filios et non vide totum locu[m] apud $\mathrm{p}[\mathrm{ro}]$ phetam." This manuscript also records the first part of the inscription. All translations of the Old Testament quotations are adapted from The holie Bible, the 1609-10 English College of Douay translation (hereafter Douay Bible), the version that hews closest to the Latin Vulgate. I have modernized the spelling in some instances and changed certain words for the sake of clarity. For this inscription (Isaiah 13:16, 18), see Douay Bible, 470. In the 1599 revision, the quotation from the Old Testament was omitted and the description rephrased: "Having begotten [infants] in damned coitus, the cruel mothers, in order that they not be exposed to the masses or that their impious sin become public, covertly arrange for [their] infants to be butchered in various ways" ("Crudeles [hev] matres qvos ex damnato coitv genverant illae infantes ne in vvlgvs efferantur earumve nefarivm scelvs innotescat diversimode trvcidari clam procvrant"). See Forcella, 6:417. 
inscription blames the mothers, participants in "illicit coitus," for the killing of their children. The characterization of the mothers as cruel implies that even if the woman in the yellow dress is interpreted to be a wet nurse, the narrative still constructs the mother, despite her expression of horror and gesture of protest, as ultimately responsible for the act of infanticide. ${ }^{30}$

If we can take the current inscriptions in the Corsia Sistina, repainted in 1642 , as indicators of the scale and layout of the fifteenth-century versions, the lettering would have been readily legible from ground level. The audience for the inscriptions would not have been limited to educated observers, as the Latin is not difficult and much of the meaning would have been comprehensible to readers of Latin-based vernaculars. ${ }^{31}$ We can also imagine forms of communal looking, with patients and visitors reading the images and inscriptions in conversation with each other. ${ }^{32}$ Throughout the cycle, the language of the inscriptions emphasizes clarity and dramatic impact. The fifteenth-century inscriptions for the Innocentine cycle each begin with the word qualiter, creating an anaphoric link between the scenes that further reinforces the compositional continuity of the imagery. Each inscription also contains biblical references, phrases from the prophecies of either Isaiah or Jeremiah, that open up the Innocentine cycle to rich metaphorical interpretation and typological readings. In the case of the infanticide scene, the textual quotations from Isaiah's prophecy of the Fall of Babylon reinforce the visual allusions to the Massacre of the Innocents, the iconography of infanticide with which contemporary viewers would have been most familiar. ${ }^{33}$ The text and image together thus construct a massacre metanarrative, shifting from the killing of infants in the Old and New Testaments to the gruesome infanticide represented in the Corsia Sistina fresco. The verbal and visual languages of massacre remain powerfully

\footnotetext{
${ }^{30}$ Interestingly, in the Trecento fresco of Bad Government painted by Ambrogio Lorenzetti in Siena's Palazzo Pubblico, the vice Crudelitas is personified by a woman torturing an infant with a snake.

${ }^{31}$ Howe, 2005, 85, makes the argument that the Latin inscriptions were for a "circumscribed audience."

${ }^{32}$ We should also not assume that viewers always regarded the scenes and read the inscriptions in narrative order. Although one of the manuscript sources, MS Barb, traces the inscriptions in narrative order, another, MS Chigi, begins with the inscriptions from the east wall scenes, reading from left to right, and then proceeds with those on the north and west walls in reverse order, beginning with the inscription under the Entrance of Sixtus into Paradise; it omits much of the south wall entirely.

${ }^{33}$ Representations of the Massacre of the Innocents in late fifteenth-century Siena were particularly grisly, but the iconography was also found in cycles of the infancy of Christ throughout Italy. In Rome, for example, the scene appears in the fifth-century mosaic decorations in the Basilica of Santa Maria Maggiore.
} 
consistent, emphasizing excessive force ("their infants shall be dashed to pieces") and spiritual damnation. The fresco shapes an image of infanticide, and the perpetrators of this crime, unlike those in the biblical references, are presented as exclusively female. ${ }^{34}$ These women were also closely connected with the birth process: wet nurses, perhaps midwives, and, most prominently, mothers.

The composition of the infanticide scene reinforces the power of the image and the text. The transition between the interior space of the birth chamber - a room to which the viewer is denied full access by the wall and columns - and the porch constitutes a shift in the relationship between the viewer and the depicted figures. While the postpartum woman in the bedroom looks out of the picture plane, acknowledging the viewer, the physical separation produced by the architecture preserves the sense of removal created by the fresco cycle as a whole. In the rest of the Corsia Sistina cycle, figures are rarely oriented outward, actively engaging the viewer; instead, they are presented in profile and three-quarter view within the pictorial space. The two women on the porch, however, move outward toward the picture plane, threatening to enter the space of the Corsia Sistina itself. It even seems that the woman in the foreground, whose eyes veer upward, is preparing to toss the bleeding infant right out of the compositional space and onto the floor of the ward. Or is she steadying herself, perhaps intending to hurl the child against the nearby pillar — in the words of Isaiah found in the fifteenth-century inscription, to "dash it to pieces"?

Her movements problematize the boundary between pictorial and ward spaces, making the viewer complicit in her actions and introducing an element of chaos into the otherwise carefully contained pictorial structure of the cycle. This spectator position is also alluded to in the fifteenth-century inscription, which describes how the child-killing will take place "before their eyes." The viewer bears witness, seeing that which was intended to be hidden. Located at the beginning of the east-wall narrative, this disorder constitutes a prequel to the coming papal intervention, a state of turmoil that will soon be rectified by the patriarchal authority of the Church.

The well-appointed bedchamber, the presence of birth attendants, and the elaborate dress of the perpetrator of infanticide serve to include women in patrician households among those condemned by both the frescoes and

\footnotetext{
${ }^{34}$ The inscriptions seem, at least in one case, to have structured the way a visitor to Santo Spirito characterized the hospital foundlings: in his Description of Italy of 1654, the Scotsman Richard Lassels described the children abandoned to the institution, using the language of the first inscription in the cycle, as "infants whom cruel mothers . . expose to hide their shame." See Chaney, 200.
} 
the inscriptions, underlining both the severity of the problem and the delicacy required of any solution. While the message of the inscriptions that accompanied the frescoes is one of unequivocal denunciation, the images open up the possibility for a patrician viewer to see the value of the foundling hospital, not just in its prevention of infanticide, but also in its ability to make unwanted additions to elite households disappear in an anonymous, orderly way. Infanticide was not the only element of these scenes that would disturb such a viewer - the representation of patrician women outside the home, conspiring with lower-class women, and being publicly visible in a capacity unauthorized by class norms would be enough to accrue shame and dishonor. ${ }^{35}$

\section{4. "All That Cast Angle into the River SHALL MOURN"}

Moving from left to right along the frescoes on the east wall of the Corsia Sistina, the lawn outside the palazzo gives way in the central portion of the wall to an undulating terrain dotted with small trees and tall grasses (fig. 4). Looming above the plain is the Castel Sant'Angelo, identifiable by the statue on the rooftop of the Archangel Michael sheathing his sword. As mentioned above, the rest of this scene, the second of four on the east wall, is obscured by the added Crucifixion fresco. We can just make out at the right a dinghy being rowed to shore by a fisherman. The darkened sky that hovers over the Castel Sant'Angelo also appears above the fisherman, linking the two damaged scenes and suggesting that they share a common setting. Although not visible, the Tiber River that must have flowed in front of the Castel Sant'Angelo in the second scene can thus be identified with the body of water visible to the right of the later Crucifixion.

The two scenes also share a single fifteenth-century inscription, which confirms the Tiber setting: "[h]ow the infants thrown from the bridge into the Tiber are captured by fishermen with their nets in place of fish. For before the child knows to call his father and his mother ... [he] shall be taken away." ${ }^{36}$ When the inscriptions in the Corsia Sistina were replaced in 1599 , this inscription was divided into two parts and amplified, allotting each scene its own explication. The two inscriptions read: "[w]hereby the

\footnotetext{
${ }^{35}$ The literature on gender and patrician honor in Renaissance Italy is vast: see, among others, Ruggiero; Brown and Davis.

${ }^{36}$ MS Barb, fols. $80^{\mathrm{v}}-81^{\mathrm{r}}$ : "Qualiter infantes de ponte in Tiberim proiecti a piscatoribus reche pro piscib[us] capiuntur. Antequam sciat puer vocare patrem su[u]m et matrem suam aufer[e]tur." For the translation of Isaiah 8:4, see Douay Bible, 463.
} 
nefarious fallen women, in order to conceal their shame, also undertake to force their offspring, brought forth in clandestine sex, down into the river from the bridge by night"; ${ }^{37}$ and "[w]ith great stupefaction and disturbance of feeling, fishermen by chance capture and drag out with nets from the Tiber, in place of fish, the cast-away infants [that had been] wretchedly submerged." "Nefarious fallen women" thus disposed of their children by "forcing them down" in the Tiber from a bridge, presumably the Ponte Sant'Angelo. The dark sky above was interpreted as a visual cue that these actions took place "by night." In the next scene, the bodies of these infants are later recovered, in place of fish, by the nets of the fishermen.

Some indication of the iconographical, if not the stylistic, content of the missing scenes on the east wall can be gleaned from the first known visual representation of the foundation legend of Santo Spirito. The legend is narrated as part of a series of twenty-two illuminated miniatures, commissioned between 1450 and 1467 in the ambit of the satellite hospital of Santo Spirito, the Hôpital Saint-Esprit in Dijon. ${ }^{39}$ These illuminations, possibly intended for a manuscript history of the Burgundian duchy, include representations of the legendary foundation of Santo Spirito by Innocent III followed by scenes of the later establishment of Saint-Esprit in Dijon by Eude III, ancestor of Duke Philip of Burgundy. ${ }^{40}$ Taken together, the Burgundian miniatures and the Corsia frescoes indicate that by the second half of the fifteenth century a conventional legend of sorts had been codified with respect to the relationship between Innocent III and the founding of Santo Spirito. No common textual source for the Innocentine narrative has been located, but, as Eunice Howe has suggested, the iconographic commonalities between the images, despite their geographical separation and diverse media, argue strongly for a common origin. ${ }^{41}$

\footnotetext{
${ }^{37}$ Forcella, 6:417: "Qvo avtem expeditivs nefariae mvlieres in clandestinvm stvprvm prolapsae flagitivm svvm obtegerent partvm in flvmen e ponte noctv detrvdi molivntur."

${ }^{38} \mathrm{Ibid}$., 418: "Piscatores in Tyberim rethia forte iniicientes loco piscivm infantes misere demersos magno cvm stvpore animiq[ue] pertvrbatione capivnt atq[ue] extrahvnt."

${ }^{39}$ For engravings after the miniatures, along with some commentary, see Peignot. The miniatures are also discussed in relation to the frescoes in the Corsia Sistina in Howe, 1978, 204-07; Walter, 1985, 825-32; Guerrini. The final miniature in the set represents an event that took place in 1450, the visit of Duke Philip the Good of Burgundy and his wife to the general chapter of the Order of the Holy Spirit in Rome, hence the terminus post quem of that year. Duke Philip, whose crest appears on the first of the miniatures, died in 1467, making it unlikely that the work dates from later.

${ }^{40}$ The illuminations are held in the Archives of the Hôpital Saint-Esprit at Dijon, now known as the Hôpital Général, in a register of bulls dating from the sixteenth century. The miniatures measure 335 by $250 \mathrm{~mm}$.
}

${ }^{41}$ Howe, 1978, 205-06. 


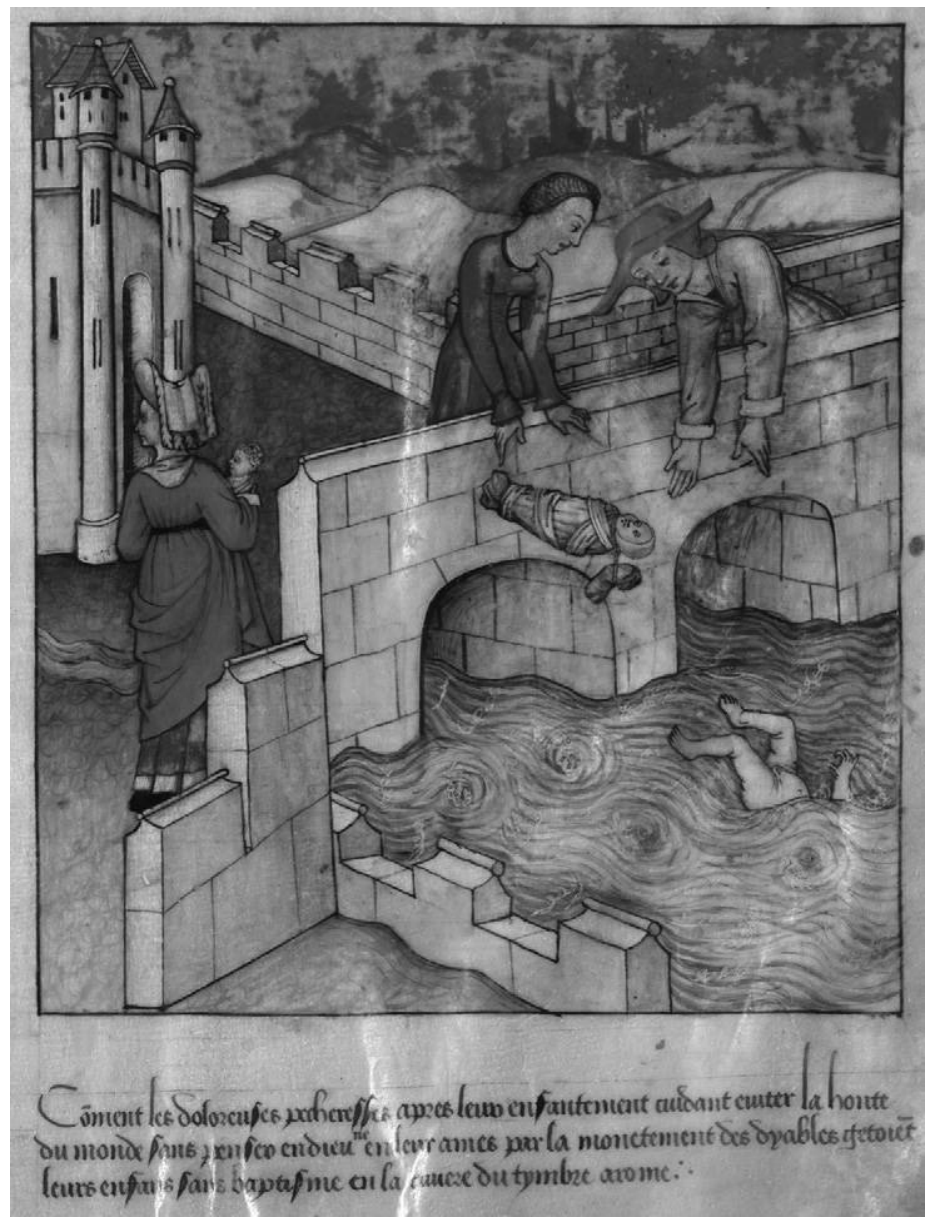

FIGURE 9. Unknown Burgundian miniaturist, Infants Thrown in the Tiber, fol. $7^{\mathrm{r}}$ of the Histoire en image de la fondation de l'Hôpital du Saint-Esprit de Dijon, illuminated manuscript on vellum, ca. 1450-67, Classé Monuments Historiques le 10/10/1891. Dijon, Centre Hospitalier Universitaire (CHU). (C) F. Petot, Archives départementales de la Côte-d'Or.

None of the miniatures corresponds to either the birth-chamber scene or the subsequent depiction of bloody infanticide. The third and sixth miniatures, however, are set at the Tiber River, though the Vatican Borgo is depicted using Burgundian conventions for representing architecture. The first of the two (fig. 9) shows two women dropping infants from a bridge into the churning river below, a description that aligns with the inscription for the second scene on the east wall of the Corsia Sistina. A third woman, 
the most fashionably dressed of the three, stands just off the bridge, holding a living child in her arms and possibly acting as a lookout for the other two. The Burgundian miniatures are also equipped with inscriptions - in French rather than Latin - and the one that accompanies this scene reads: " $[\mathrm{h}]$ ow, after their parturition, the grievous sinners, presuming to avoid the shame of the world without thinking of God or of their souls, by the counsel of devils throw away their children without baptism in the river Tiber at Rome." ${ }^{42}$ Without baptism, the inscription emphasizes, the sinful women getoient (throw away) their children in the Tiber. ${ }^{43}$ Only the legs and an arm of one of the discarded infants remain visible above the waves, indicating the naked child's futile struggle against the swirling current and thus reaffirming that the child was tossed in alive. In contrast, the other infant is wrapped head to foot in swaddling bands, with a weight attached to its neck so that the body will not float incriminatingly to the surface.

The sixth miniature (fig. 10), which corresponds to the damaged third scene on the east wall of the Corsia Sistina, shows a small boat with four fisherman, who lift up a net filled with babies. A child, with open eyes but presumably dead, is cradled in the arms of one of the men. The bodies of five additional infants lie like so many fish at the bottom of the net. The inscription of this miniature describes how the fishermen and the servants of the pope retrieve the "little infants" who had been thrown in the river. ${ }^{44}$ The fresco covered by the Crucifixion in the Corsia Sistina probably also featured a boat — perhaps the same one that is partially visible — with several fishermen using their net to retrieve discarded babies.

Although the miniatures and the fresco cycle share a common iconography, their respective audiences were quite distinct. While the Dijon miniatures, each one barely larger than a quarto page, were destined for a small audience of Burgundian elites located over 500 miles from the Tiber, the

\footnotetext{
${ }^{42}$ The inscription is transcribed in Peignot, 24: "Comment les doloreuses pecheresses aprez leur enfantement cuidant eviter la honte du monde sans penser en Dieu ne en leur ames par la monetement des dyables getoient leurs enfans sans baptisme en la riviere du tymbre a rome."

${ }^{43}$ The Italian equivalent, gettare, is the base for gettatello, a common term for a foundling.

${ }^{44}$ For the inscription, see Peignot, 29. In the Dijon version, two scenes take place between the throwing of the infants from the bridge and their extraction from the Tiber. After the bridge scene, the fourth miniature shows Pope Innocent III receiving a visit from an angel while lying ill in bed. The angel instructs Innocent to send his agents to fish in a certain area of the river. The fish caught there, the angel says, would be a medicine for both Innocent's body and his soul. The fifth miniature represents the pope, still in bed, meeting with his cardinals to tell them of the angel's visit. The cardinals, in turn, decide to advocate for the fishing. This fishing, conducted by fishermen and servants of the pope, is the subject of the sixth miniature.
} 


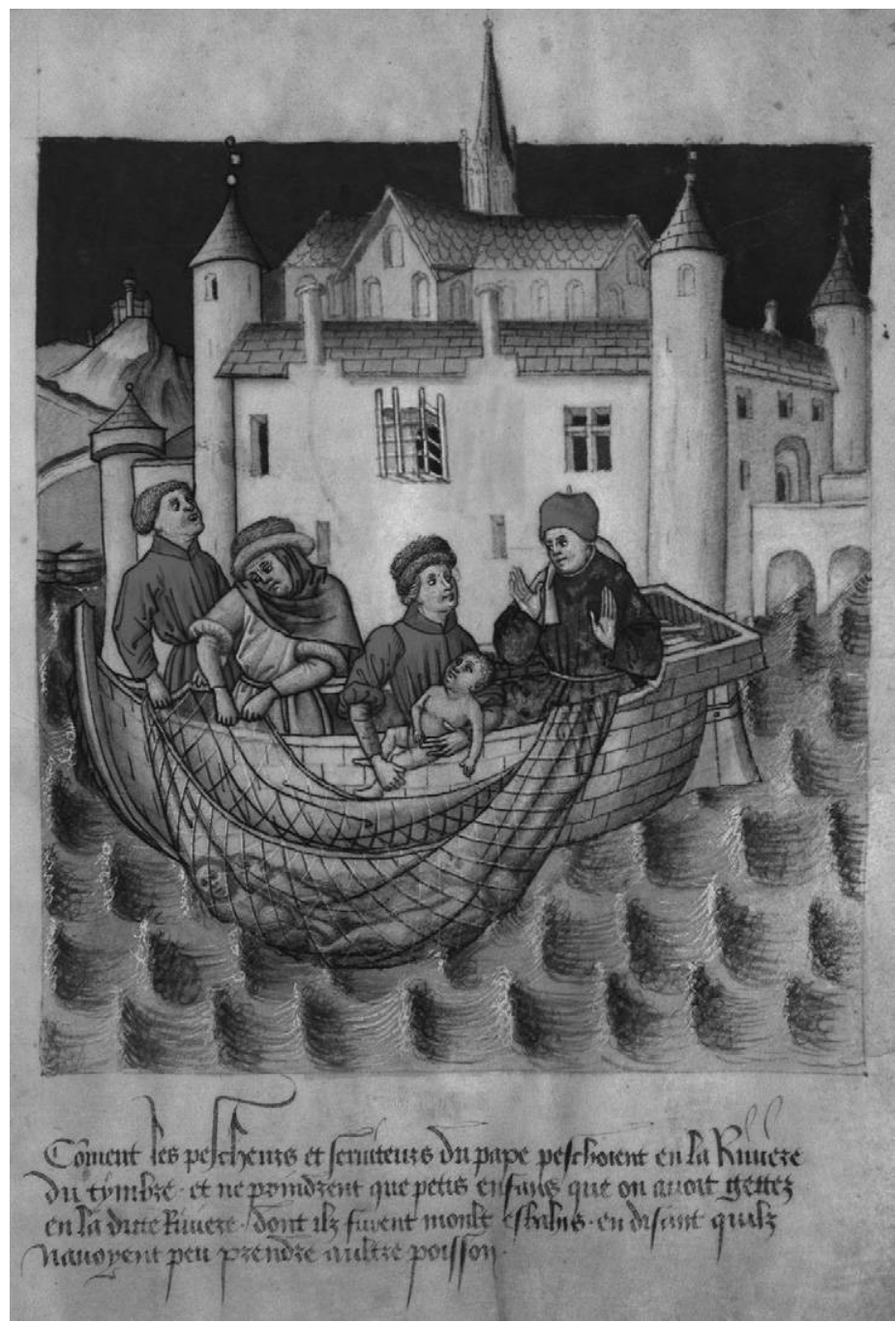

FIGURE 10. Unknown Burgundian miniaturist, Infants Fished from the Tiber, fol. $10^{\mathrm{r}}$ of the Histoire en image de la fondation de l'Hôpital du Saint-Esprit de Dijon, illuminated manuscript on vellum, ca. 1450-67, Classé Monuments Historiques le 10/10/1891. Dijon, Centre Hospitalier Universitaire (CHU). C F. Petot, Archives départementales de la Côte-d'Or.

frescoes in the Corsia Sistina were addressed to a very different spectator. The identifiable presence of the Castel Sant'Angelo and the Tiber in the fresco would have brought into greater clarity the relationship between the depicted scene and viewers' knowledge of their immediate surroundings, as the actual 
Sant'Angelo bridge and Tiber River were located directly behind the wall on which the scenes were painted. Although a large percentage of abandoned children taken in by the hospital were from the campagna (countryside), the Innocentine narrative constructs the mission of Santo Spirito as a profoundly local, Roman one. ${ }^{45}$ The hero of the narrative is a pope, the setting is the Tiber in front of Castel Sant'Angelo, and the villains are, by implication, Roman women. Emphasizing the proximity of the problem of infanticide would have underscored the urgency of the hospital's mission: this was happening, not just in Rome, the frescoes tell us, but right outside the walls of the hospital.

At an unknown time before 1600, a second depiction of the fishermen catching infants in their nets was painted in the Corsia Sistina. In his 1601 treatise on Roman charitable institutions, Camillo Fanucci describes "[c]ertain fisherman having found certain little children in their nets in place of fish: as demonstrated by the picture near the middle door of the hospital, in front of the chapel of the most divine Sacrament, and again in the room of the said hospital, where in addition to the paintings one finds these inscriptions." ${ }^{26}$ Fanucci describes this image, which is no longer visible, as placed facing the chapel, near the door. ${ }^{47}$ The chapel of the Corsia Sistina was located in the crossing, the section of the ward accessed by a visitor immediately upon entering through the main door from the Borgo Santo Spirito. This repetition of the fishing narrative places additional emphasis on the macabre foundation myth of the hospital, reinforcing the perception of a dire need for foundling care and the honorable service provided by Santo Spirito to the local community. Both depictions of the fishing episode were painted in conspicuous spaces by the ward's exits, reminding the viewer in graphic terms of the crucial importance of the

\footnotetext{
${ }^{45}$ The archives of Santo Spirito, held at the Archivio di Stato in Rome, contain very little information about foundling care at the hospital before the sixteenth century. I have located late fifteenth- and early sixteenth-century notarial records detailing the adoption, marriage, and apprenticing of proietti and proiette (male and female foundlings), but no records to compare with those held at the well-studied archive of the Innocenti hospital in Florence. For the care of abandoned children at Santo Spirito, including discussions of provenance, primarily for later periods, see Schiavoni; Dominici; Surdacki.

${ }^{46}$ Fanucci, 23: "Per havere certi pescatori in luogo di pesci trovati certi fanciullini nelle loro reti: come dimostra il ritratto vicino alla porta di mezzo dello Spedale, à fronte alla Cappella del divinissimo Sacramento, \& ancora nella stanza di detto Spedale, dove oltra alle dipinture si scorgono queste inscrittioni." As far as I know, Fanucci's identification of the second iteration of the fishing narrative has gone unnoticed in the scholarly literature.

${ }^{47}$ Based on Fanucci's account, the only likely location is the counterfaçade of the main entrance, where today we see a later fresco of the Annunciation. The Annunciation occupies a lunette above the door, while two seventeenth-century frescoes frame the door on either side. Any one of these three zones could have been the location of the image he describes.
} 


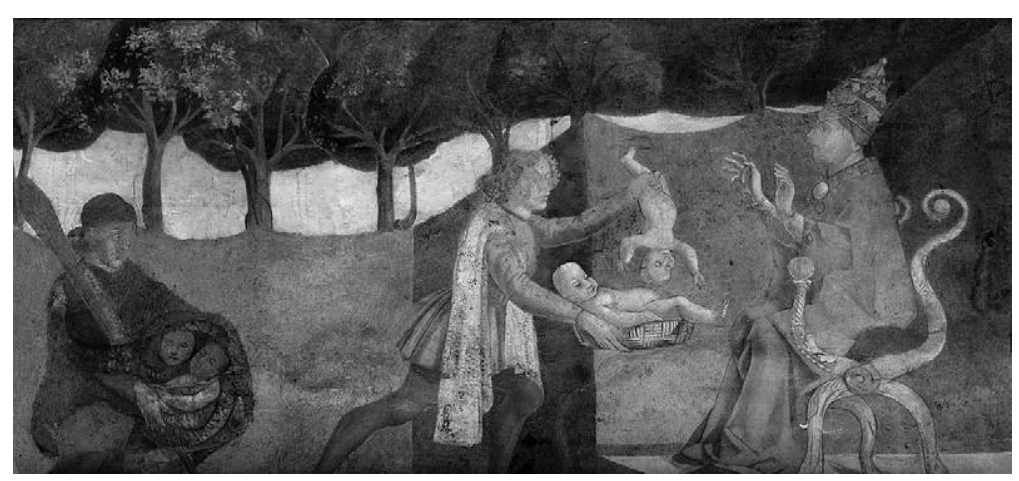

FIGURE 11. Unknown artists, Infants Presented to Innocent III(detail), late 1470s. East wall, Corsia Sistina, Ospedale di Santo Spirito in Sassia, Rome. Author's photograph.

hospital's mission. Following the example of Last Judgment frescoes placed on exit walls, ${ }^{48}$ the two fishing scenes were situated strategically so that their violent imagery would remain with the observer after he or she entered or exited the Corsia Sistina. ${ }^{49}$ Just beyond both exits, the Tiber itself served to reinforce the message of the frescoes, the actual river attaching current relevance to the fictionalized legend of the hospital's foundation. The enduring presence of the river, the Ponte, and the Castello worked to compress the elapsed time, making the urgency that purportedly inspired the original foundation vividly present in the Rome of the late fifteenth century.

The final scene on the east wall, Infants Presented to Innocent III (fig. 11), shows the fishermen presenting the bodies of several infants to Pope Innocent III, who appears seated on an ornate throne, dressed in papal vestments. At the left, one fisherman stands below the dais of the pope, cradling two infants in a cloth wrap. In the center, another man, more elegantly dressed, strides toward Innocent, holding up one dead child by the leg while carrying another in a woven basket. ${ }^{50}$ He presses the little corpses

${ }^{48}$ For example, the one painted ca. 1290 by Pietro Cavallini in Santa Cecilia in Trastevere.

${ }^{49}$ The presence of women in the Corsia Sistina can neither be confirmed nor discounted. I have come across no prescriptive sources that would indicate that it was even a topic of discussion.

${ }^{50}$ The text in the Dijon miniatures indicates that the fishermen were, in fact, employees of the pope. This is not made explicit in the Corsia Sistina, but it would explain their attire. Walter, 1985,822 , identifies the left-hand man as a fisherman and the right-hand man as a courtier. The inclusion of the basket may have reminded some viewers of the iconography of the finding of Moses, who could also be characterized as a foundling. While The Finding of Moses was not a commonly represented subject in fifteenth-century Italy, Sixtus himself commissioned Perugino to paint a version (now lost) on the altar wall of the Sistine Chapel in 1481. However, I have found no contemporary visual (or textual) evidence that specifically incorporates Moses imagery into the visual rhetoric of infant abandonment. 
upon the pope, who throws up his hands in response to the grisly sight. The inscription below describes the action with terse clarity: "[i]n what manner the fishermen bring the children found [by them] to Innocent III, which shameful act is immediately condemned by him. ${ }^{51}$ The fishers shall lament and all that cast angle into the river shall mourn." 52

The raised arms of the pope recall images of Herod's reaction to the presentation of the head of John the Baptist. ${ }^{53}$ The Santo Spirito fresco uses the Baptist iconography as a tool for making the unusual subject matter legible, even presenting the dead infant in a shallow basket that recalls the salver typically used for the Baptist's head. Innocent's gesture recalls Herod's as a cue to the viewer that the pope is responding, like Herod, to a gruesome sight. Yet Herod, though momentarily repelled, was fundamentally complicit in the Baptist's death. In contrast, as a witness to violence, Innocent instead responds wisely. In this manner he is configured as a Solomon type, a connection reinforced by the composition of the scene. ${ }^{54}$ In the narratives, infants - in one case imperiled, in the other already dead - are presented both to the pope and to the king, as a test of their perspicacity. ${ }^{55}$ In response, both rulers choose the appropriate course of action, performing their ruling authority through the execution of sound judgment.

The disorder of the female-dominated spaces of the confinement chamber and porch, and the macabre discoveries of the fishermen in the waters of the Tiber, constitute an unacceptable status quo. The appropriate response to this state of affairs is the intervention of papal authority, here embodied in the figure of Innocent. On the north, south, and west walls of the Corsia Sistina, each narrative scene includes either Pope Innocent III or Pope Sixtus IV authorizing, observing, or receiving something or someone. On the east wall, in contrast, Innocent appears only in the final of the four scenes. In the context of the larger decorative program, therefore, the representation of Innocent on the east wall unites the entire wall as one composite narrative. The disposition of the enthroned pope - facing toward, rather than away from, the preceding scenes — involves him not just

${ }^{51}$ MS Barb, fol. 81 ${ }^{\mathrm{r}}$ : "Qualiter Piscatores compertos pueros, Innocent.o tertio d[e]fer[u]nt quod indignum facinus illico detestatur."

${ }^{52}$ MS Chigi, fol. $175^{\mathrm{r}}$ : "Merebunt piscatores et lugebunt o[m]nes in flumen expandentes rete." For the translation of Isaiah 19:8, see Douay Bible, 476.

${ }^{53}$ For example, as in Donatello's version on the baptismal font in the Siena Baptistery.

${ }^{54}$ I thank Megan Holmes for this suggestion. The lion paws on Innocent's throne also reference Solomon's throne of wisdom: Howe, 2005, 86n50.

${ }^{55}$ Although the focus of Solomon's attention was a living infant, representations of the Judgment of Solomon from the time typically also include the dead child. See, for example, the version on the Quattrocento birth tray in the collection of the Virginia Museum of Fine Arts. 
in the immediate action of the presentation of the dead infants, but also in the narrative of the east wall as a whole. The placement of Innocent's body constitutes a compositional break that divides the east-wall scenes from those in the rest of the ward, underscoring the shift between the chaos of the situation before the intervention of the papacy and the judiciously administrated stability that follows it. ${ }^{56}$

In the representation of the confinement chamber and the subsequent infanticide, the eyes of the postpartum mother (fig. 6) and those of the woman holding the bleeding infant (fig. 7) are oversized. The frescoes were not intended to be viewed closely, and optical corrections of this kind were used to make certain aspects of the images legible to the viewer standing below. The representation of Innocent, and, later in the cycle, of Sixtus, in strict profile, unchanging in their patriarchal authority, contrasts with the full-faced, wide-eyed women of the earlier scenes. The frescoes thus thematize the acts of looking and being seen, of witnessing infanticide. Subverting the attempts of the women to conceal their actions, the compositional structure of the east wall exposes the "shameful acts" of the "cruel mothers" to the omniscient eyes of Pope Innocent. This pictorial strategy reveals the patriarchal authorities' concern about the possibility of women secretly disposing of their children, and concealing the evidence of their crimes undetected in the many hiding places provided by the urban environment: the river, the well, the ditch. ${ }^{57}$ St. Bernardino of Siena elaborated precisely this concern in a sermon he delivered in Florence fifty years earlier: "Listen, and you will hear voices rising to Heaven, crying, 'Vengeance! Vengeance! O God!' . . . What are these cries? They are the voices of the innocent babies thrown into your Arno and your privies or buried alive in your gardens and your stables, to avoid the world's shame, and sometimes without baptism." 58

${ }^{56}$ As Walter, 1985, 856-57, points out, the fishing of infants in the foundation legend also resonates powerfully with the biblical metaphor of Saint Peter the fisherman. As the heir to the throne of Peter, the rock on which Christ built his church, Pope Innocent operates here as a kind of fisherman, albeit one whose direct involvement with the act of fishing is left ambiguous. The metaphorical link to Peter the fisherman highlights the unnaturalness evoked earlier in the narrative by the awkward handling of the infant. In this case, customary fishing is unnaturally inverted through the appearance of babies, rather than fish, in the nets.

${ }^{57}$ Unsurprisingly, the rhetoric of infanticide took into account the varying topographical features of different communities. In cities with rivers, like Florence and Rome, those waterways were cited as the primary site for infanticide. In a landlocked city like Siena, child-killing was thought to occur at privies, wells, and ditches. In Venice, the canals were described as places for the corpses of the city's unwanted children.

${ }^{58}$ Quoted in Origo, 198. 
In the fresco, the pope is shown acting to fill a void in the municipal welfare system by providing a place for shame-ridden women to deposit their unwanted children. This Solomon-like wisdom remedies the disorder manifested in the appearance of dead babies in places properly populated by living fish, mending the tear in the social fabric of the city through the foundation of the hospital of Santo Spirito. This decision is in turn valorized by the fresco cycle as a whole, which proclaims the social utility of several papal building projects.

\section{INNOCENTINE BUILDING}

The south wall of the Corsia Sistina begins with the scenes of the construction of Santo Spirito by Innocent III and ends with the rebuilding of the hospital by Sixtus IV, creating a visual parallel between Innocentine building and Sistine renovatio. Like the frescoes on the east wall, which operate both independently and as a unified whole, the scenes of papal subventions toward Santo Spirito work on multiple levels. The frescoes that narrate Innocent's establishment of the hospital form the second part of the foundation legend begun on the east wall, with the pope responding to the purported infanticides with the construction of Santo Spirito. Similarly, the scenes of Sixtus's second foundation of the hospital operate as part of the larger biographical structure of the fresco cycle, depicting the interventions he undertook as pope in honor of the Jubilee Year of 1475. But taken together, the two narratives function as a pictorial rumination on the particularly Roman theme of renovatio and the application of that formulation to the ideal care of foundlings.

Following the Infants Presented to Innocent III in the narrative, the first scene on the south wall, the Dream of Innocent III (fig. 12), represents Innocent asleep in bed, attended by two young men. An angel enters his bedchamber, extending an index finger in a gesture of admonition. At the left of the composition looms the Torre dei Conti, the tower erected by Innocent near the Forum of Trajan. ${ }^{59}$ The pope's bedchamber is sumptuously decorated, complete with embroidered bedspread and coffered canopy, and Innocent sleeps with his papal tiara on, signifying the unchanging nature of his papal authority. ${ }^{60}$ The actions of the angel are

\footnotetext{
${ }^{59}$ The Torre dei Conti would also have alluded to Innocent's building campaigns: see Howe, 2005, 86.

${ }^{60}$ Innocent is also represented sleeping in his papal vestments in the late thirteenth-century fresco of the Dream of Innocent III in the Upper Church of San Francesco at Assisi.
} 


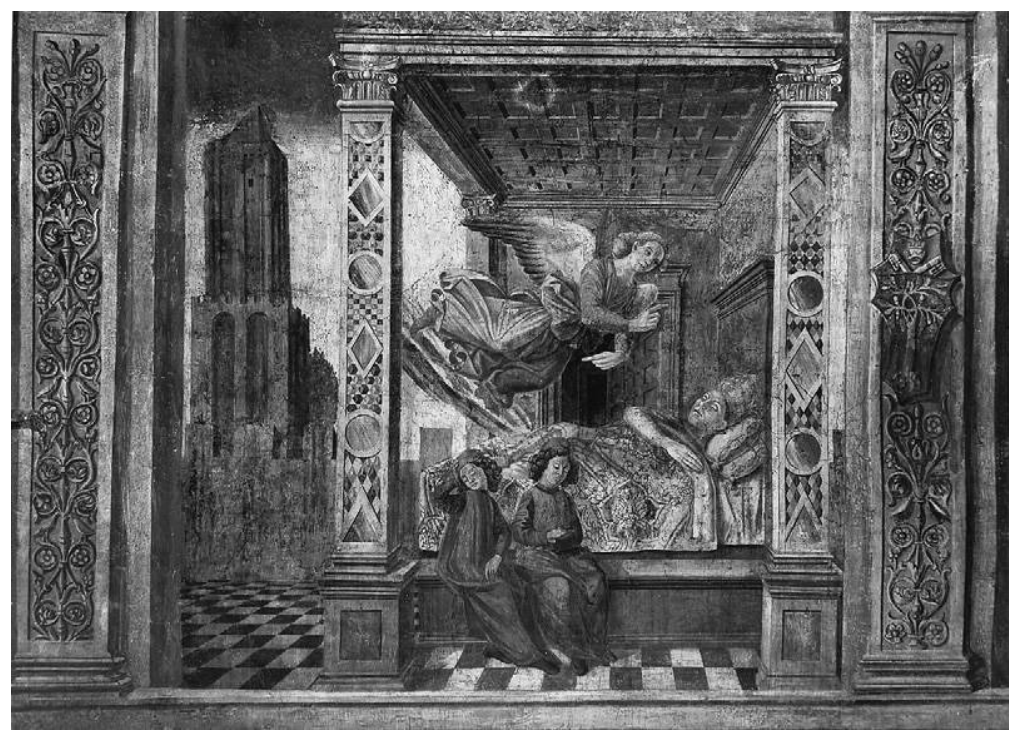

FIGURE 12. Unknown artists, Dream of Innocent III, late 1470s. South wall, Corsia Sistina, Ospedale di Santo Spirito in Sassia, Rome. (c) Eunice D. Howe.

explained by the inscription underneath the scene. The fifteenth-century version reads: "Here Innocent III dei Conti is warned by the angel to build the hospital for the saving of foundlings, and [the angel] designates a place in Sassia, where they would be bound to come from everywhere to be received and educated. ${ }^{61}$ I will say to the north ... and to the south, Hinder not: bring my sons from far, and my daughters from the ends of the earth." ${ }^{162}$

As in the inscription in the Vatican Library fresco, Santo Spirito is characterized here as a foundling hospital rather than as a multifunctional institution for the sick, pilgrims, and others. The inscription specifies that the hospital will serve to save the foundlings from the tragedy of infanticide. This deliberate reorientation was not based on a misconception about the hospital's historical multifunctional status: the bulls issued by popes through the centuries, from Innocent to Sixtus and beyond, continually reinforce the hospital's diverse functions. Further outlined in the inscription is the form

${ }^{61} \mathrm{MS}$ Barb, fol. 81 ${ }^{\mathrm{r}-\mathrm{v}}$ : "Hic Innoc.us tertius de Comitib[us] admonitur per angelum, ut hospitale pro salvandis expositis edificet, locumque in Saxia designet, ubi passi omnes recipi et educari debeant."

${ }^{62}$ MS Urb, fol. 11 ${ }^{\mathrm{v}}$ : "Dicam Aquiloni da, et Austro noli prohibet affer filios meos de longinquo et filias meas ab extremis terrae." For the translation of Isaiah 43:6, see Douay Bible, 512. 
that the care of foundlings would take at Santo Spirito: they were to be sheltered and, significantly, educated. Beyond remedying the spiritual crisis brought on by the killing of unbaptized infants, the establishment of the hospital would provide the means with which to reintegrate these unwanted children into society. The quotation from the book of Isaiah goes even further, suggesting that the foundlings brought to Santo Spirito become the sons and daughters of the pope himself. ${ }^{63}$

The local specificity of the east-wall narrative and the Torre dei Conti is complicated by the inscription, which positions Santo Spirito as a foundling hospital on a global scale. Like the pilgrims that come from far and wide to visit the holy treasures of Rome, so too, the inscription proposes, will abandoned children "from everywhere" find their way to the welcoming arms of Innocent and Santo Spirito. The use of the quotations from Isaiah to specify that girls as well as boys were to be received at the hospital echoes the description of foundling care at Santo Spirito made by Nicholas IV in the earliest papal bull to touch upon the subject. In Charitatis opera of 1291, Nicholas writes of "infants of both sexes abandoned to our hospital." Writing three years later, Boniface VIII, in his In hospitali Nostro of 1294, the second papal bull to mention foundlings, also describes "infants . . . willingly received, and . . . educated" at Santo Spirito. ${ }^{65}$ Although the language is formulaic, the inscription thus references, perhaps intentionally, the conceptions of ideal care of foundlings at the hospital in circulation as close as possible to the time of Innocent III. ${ }^{66}$

The penultimate scene in the Innocentine cycle is preceded by the figure of King Solomon holding a scroll, a pictorial reaffirmation of the Solomonic wisdom of Innocent's decision articulated in the Infants Presented to Innocent III. In Innocent III Builds Santo Spirito (fig. 13), Innocent enters the scene from the right, on horseback and in the company of two cardinals and a page. In the background the construction of the hospital is well underway, with six men working on a sizable brick structure. Another two occupy the foreground: one is digging in an area pointed to by the other man, who turns

${ }^{63}$ Sources from later periods indicate that the foundlings of Santo Spirito were commonly referred to as figli and figlie del papa (sons and daughters of the pope), but I have found no documentation confirming that this was the case during the pontificate of Sixtus.

${ }^{64} \mathrm{ASR}$, OSS, 1, fol. 42 ${ }^{\mathrm{v}}$ : "infantes utriusq[ue] sexus in hospitali nostro expositos."

${ }^{65}$ Ibid., fol. $49^{\mathrm{r}}$ : "infantes . . . voluntate susciptis, et . . . educandis."

${ }^{66}$ While references to the reception and alimentation of foundlings continue in the papal bulls of the fifteenth century, the conventional language referring to infants of both sexes does not. The fifteenth-century bulls do refer to girls and boys (puellas and pueri), but not infantes of both sexes. 


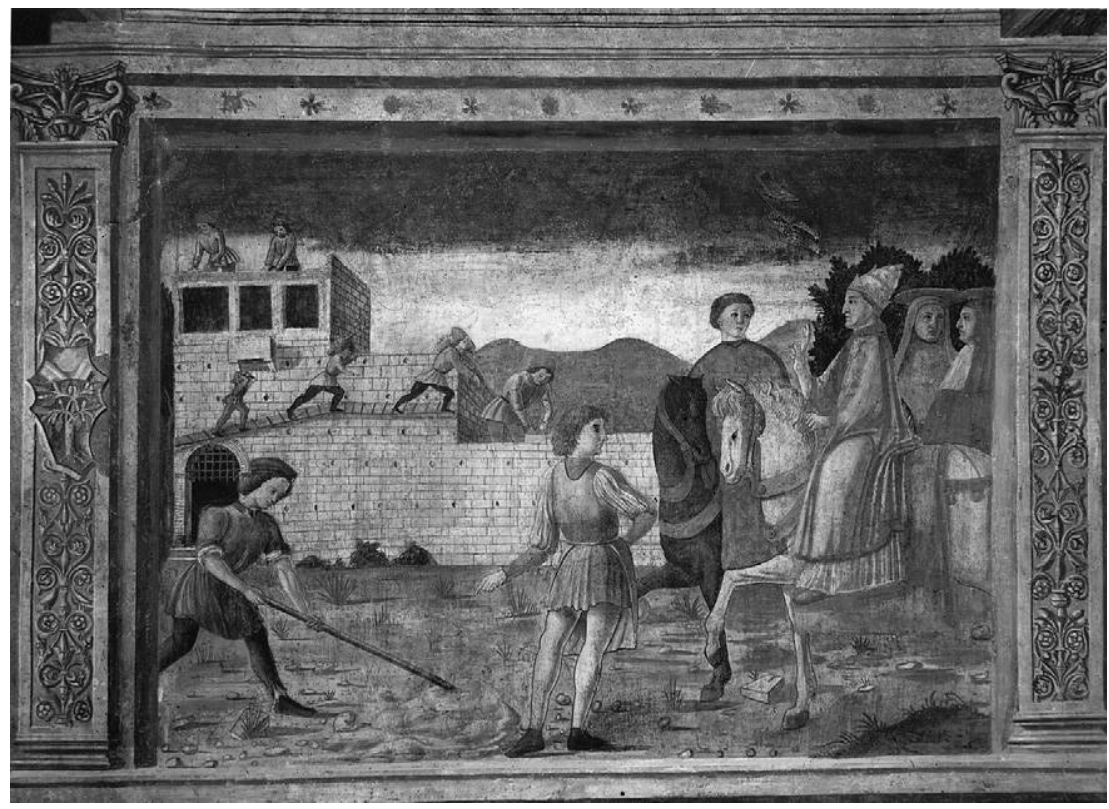

FIGURE 13. Unknown artists, Innocent III Builds Santo Spirito, late 1470s. South wall, Corsia Sistina, Ospedale di Santo Spirito in Sassia, Rome. (C) Eunice D. Howe.

to face Innocent. The original inscription for this scene describes the actions: "Here Innocent III, obeying the warning of the angel, causes the hospital to be founded and built in honor of the Holy Spirit. ${ }^{67}$ This is my rest, refresh the weary; and this is my refreshing. . . . Help the poor." 68 The inscription indicates that the fresco represents the actions taken by Innocent in response to the visit from the angel. The pope has designated the spot "in Sassia," specified by the angel as the location of the hospital. The background of the scene shows the project at an advanced stage, suggesting a lapse of time between the background and foreground actions. By making specific reference to Santo Spirito as a refuge for the weary and the impoverished, the inscription also alludes indirectly to the centrality of the subvention of pilgrims to the hospital's charitable mission.

${ }^{67}$ MS Barb, fol. 81" : "Hic Innoc.us tertius Angelic[a]e monitioni parens, in honore[m] Sti sp[irit]us hos[pital]e fu[n]dari et erigi fecit."

${ }^{68} \mathrm{MS}$ Urb, fol. $12^{\mathrm{r}}$ : "Haec est requies mea, reficite lassum, et hoc e[st] refrigerium meum, subvenite egeno." For the translation of Isaiah 28:12, see Douay Bible, 488. The phrase subvenite egeno does not come from the Bible. 
The final scene in the Innocentine narrative represents the pope confirming the Order of Santo Spirito, presenting the habit of the order to the hospital attendants, and bestowing the Veronica cloth, one of the Church's greatest relics, to the hospital. ${ }^{69}$ Unfortunately, this fresco has been almost completely destroyed by the later installation of a window, making it very difficult to reconstruct the action. At the right of the composition Innocent is depicted enthroned under an all'antica canopy supported by Corinthian columns. Beyond the foreground is a mountain range and at the left of the window there is a brick wall. The rest of the fresco has been lost, but it is described in the original inscription: "Innocent III institutes the religious servants of the hospital and gives them the Sudarium and the habit, and entrusts to them the duty to keep the foundlings healthy and to educate them with the greatest care. Leave thy orphans, I will allow them to live."

The words of Jeremiah expand upon the description of the care of foundlings at Santo Spirito begun in the inscription below the Dream of Innocent III. Through the prophet's words, Innocent tells the shamed women represented on the east wall that he will welcome their "orphans" by entrusting their health and education to the Order of Santo Spirito. The inscription makes explicit the paternal nature of Innocent's construction of the hospital: the pope assumes the role vacated by the absent father of the abandoned child, thereby endowing the act of hospital-building with a strongly gendered resonance. Patrons and supporters of foundling care were often represented as surrogate guardians in visual and textual sources associated with hospitals throughout Italy in the fifteenth century. ${ }^{71}$ In the case of Santo Spirito, however, the pope, welcoming "[his] sons from far, and [his] daughters from the ends of the earth," is constructed simultaneously as the Father of the Church and as the patriarchal guardian of the hospital foundlings.

\footnotetext{
${ }^{69}$ Fanucci, 23, claims that Innocent gave the Sudarium to the Hospital of Santo Spirito, but that it was taken back by Pope Pius II and replaced with other relics. It is unclear whether or not the Sudarium, now held at St. Peter's Basilica, was ever physically housed at the hospital. On this issue, see Canezza, 44.

${ }^{70} \mathrm{MS}$ Urb, fol. 12 $2^{\mathrm{r}}$ : "Hic Innocentius iii Religiosos hospitali servientes instituit, eisq[ue] assudarium, et habitum donat, et un expositor[um] saluti, ed educationi assistant, attenti[ssi]me mandat. Relinque pupillos tuos, et ego faciam eos viver[e]." For the translation of Jeremiah 49:11, see Douay Bible, 637. The Douay Bible translates the Latin pupillos as "pupilles," an Anglicization of pupilli, which John Florio defines in his Italian-English Dictionary of 1611 as "a pupill, a warde, an orphlin, a fatherlesse child": see Florio, 411.
}

${ }^{71}$ See Presciutti, 2008. 
This scene also has another ideological function, that of obscuring the Order of Santo Spirito's French origins. ${ }^{72}$ It was a native of France, Guy de Montpellier, who founded the hospitaller Order of the Holy Spirit during the twelfth century, establishing numerous hospices throughout his native country and later in Italy and beyond. ${ }^{73}$ Innocent and his successors worked to relocate control of the order from France to Rome, making the Roman hospital the order's headquarters. ${ }^{74}$ This controversy is neatly circumvented in the fifteenth-century retelling, partly by presenting Innocent's institution of the order as its moment of origin and by peppering the Innocentine cycle with Roman landmarks - the Castel Sant'Angelo, the Tiber, the Torre dei Conti - thereby reinforcing the local status of the narrative.

The inscription also delimits the activities of the order by describing them as focused exclusively on the care of foundlings. The hospitaller order was as variegated in its dedications as the hospital of Santo Spirito itself, but the inscription suggests that the group was constituted by Innocent specifically to provide support staff for the hospital's stewardship of abandoned children. ${ }^{75}$ Presenting Santo Spirito visually and rhetorically as a foundling hospital worked simultaneously to magnify the importance of the pope - as surrogate guardian, urban administrator, and generative builder - and to subordinate the role played by the Order of Santo Spirito.

\section{SiSTINE RENOVATIO}

The story of the second foundation of Santo Spirito by Sixtus IV is represented on the ward's southwestern wall. It is placed explicitly within the context of the urban construction projects undertaken by Sixtus during the early years of his pontificate. The inscription on Melozzo da Forli's Vatican fresco, quoted at the beginning of this article, situated Santo Spirito among other urban developments identified as the most important achievements of his papacy. Similarly, the Corsia Sistina cycle places primary emphasis on Sixtus's numerous manipulations of Rome's urban fabric. Sixtus's construction of the Ponte Sisto and his repair of aqueducts demonstrated his control of the waterways of the city, whereas his rebuilding of Santo

${ }^{72}$ On the hospitaller order, see $\mathrm{n} 7$ above.

${ }^{73}$ See De Angelis, 1962.

${ }^{74}$ See Howe, 1978, 6-15.

${ }^{75}$ An illuminated version of the Liber Regulae of the Order of Santo Spirito, dated to the fourteenth century, enumerates the regulations the order was prescribed to follow. For a facsimile of the Liber Regulae, see La Cava. On the manuscript, see, most recently, Drossbach, 2007. 
Spirito purported to prevent the misuse of the same through the clandestine drowning of unwanted infants. Building, in particular papal rebuilding, and the importance of institutional care for abandoned children emerge as the twin themes of the south wall of the Corsia Sistina, and the two mutually reinforce each other visually at every opportunity.

Platina's inscription for the Vatican fresco positions Sixtus IV as a new Augustus - and, by extension, the papacy as a new empire — reshaping the urban fabric of the city through massive building campaigns. ${ }^{76}$ The inscription appears again, verbatim, below the fresco on the north wall of the Corsia Sistina representing Sixtus IV Visiting the Vatican Library. ${ }^{77}$ While Augustus was said to have found a Rome made of brick and transformed it into marble, the Sixtus of Platina's inscription returned a decayed and crumbling city to its ancient magnificence. ${ }^{78}$ This characterization of Sixtus is elaborated in the Corsia Sistina fresco cycle, which, by means of a pictorial inventory of the various building campaigns of the pope, fashions encomia through unrelenting visual reiteration. We see Sixtus authorizing the building of the Ponte Sisto, the demolition of the old hospital of Santo Spirito, the construction of the new hospital, and the building of the church of Santa Maria del Popolo. At the end of the cycle, just before he is shown being welcomed into paradise by St. Peter himself, Sixtus is represented as the ideal Christian Augustus: supported by the Virgin and St. Francis, the kneeling pope presents his building projects to a blessing God.

The fundamental role played by the Innocentine scenes as prequel to the Sistine narrative is underscored by the visual links made between the cycles. In the scene of his building of Santo Spirito, Innocent is represented in full papal regalia, and accompanied by two cardinals. In most of the Sistine scenes, Sixtus is similarly shown in profile, at the edge of the composition, and joined by two cardinals. Like the blood flowing from the head of the infant on the east wall, the red of the cardinals' robes easily catches the eye, even the eye of an observer many feet below, allowing the papal entourage to guide the viewer to the figure of Sixtus in each of the narrative frescoes. The similar depiction of Innocent provides a clear and unambiguous pictorial

${ }^{76}$ On Sixtus's self-presentation as a new Augustus, see Blondin, esp. 22. In his praise of the pope, humanist Ludovico Lazzarelli specifically linked Sixtus's urban restoration projects with those undertaken by Augustus: ibid., 2-3.

${ }^{77}$ Interestingly, this is the only inscription in the ward that remained the same through the 1599 and 1642 renovations.

${ }^{78}$ In the biography of Sixtus he included in his Commentariorum urbanorum of 1506, the encyclopedist Raffaele Maffei (1451-1522) aligned the pope's campaign of urban renewal with Augustus's transformation of ancient Rome into a city of marble. See Lee, 123-24; Blondin, 3n5; Howe, 2005, 70. 


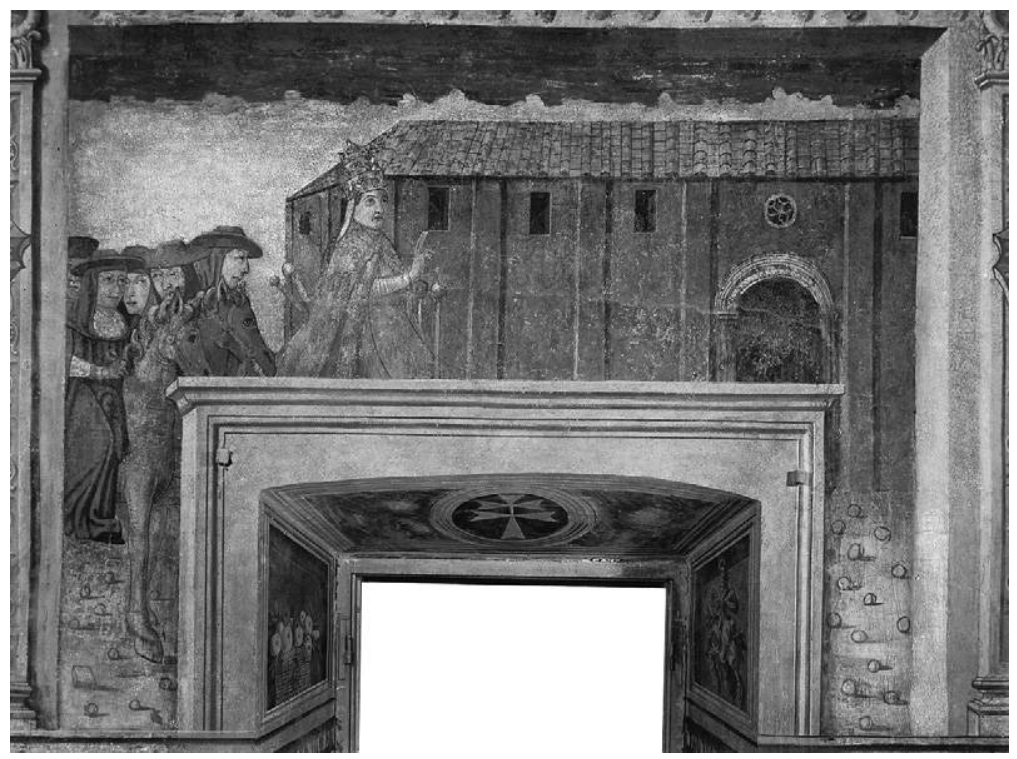

FIGURE 14. Unknown artists, Sixtus IV Visits the Old Hospital, late 1470s. South wall, Corsia Sistina, Ospedale di Santo Spirito in Sassia, Rome. (C) Eunice D. Howe.

link between the two popes featured in the ward frescoes, and between the two narrative cycles. The similar representations of the popes allow the actions of Innocent and Sixtus to be seen as joined over the distance of centuries, the two popes united in their charity toward abandoned children. Innocent III Builds Santo Spirito is also the first in the cycle to associate the person of the pope with the action of building. The scene of Innocent "causing [Santo Spirito] to be founded," as the inscription states, combines the papal authorization with the commencement of construction, as pope and patron are one and the same. In the context of the parallel narratives of papal building and rebuilding, Innocent functions here as an inspiration to Sixtus, setting a precedent for the later pope to surpass.

The first of the scenes representing the rebuilding of Santo Spirito, Sixtus IV Visits the Old Hospital (fig. 14), is partially obliterated by the later installation of a window. At the left a coterie of cardinals on horseback follows an enthroned Sixtus. The old hospital of Santo Spirito looms large in the background of the scene. It appears structurally sound at first glance, but the small rocks that litter the ground below signal to the viewer that this is a site of degradation and disorder. The inscription below makes this explicit: "[n]ext [Sixtus], his mind turned to restoring pious places, visits this 
hospital, which had nearly collapsed from age, [and decides to] restore it from its foundations." ${ }^{\text {79 }}$ The language of the inscription and the composition itself situate Sixtus as the first to recognize the decrepit physical condition of the hospital, a crucial element of the cycle's omission of all earlier papal concessions toward Santo Spirito that occurred between the papacies of Innocent and Sixtus. In fact, several of Sixtus's Quattrocento predecessors noted the ruinous state of the hospital: for example, in his Inter praecipuas of 1446, Eugenius IV categorized Santo Spirito as "quasi ad ruinam collapsis," and Calixtus III, in his bull Etsi cunctorum of 1457, described the hospital as on the verge of "totalem ruinam. ${ }^{" 80}$ Eugenius IV's attentions toward the hospital, which included restoration projects and the reinstatement of the hospital confraternity, are conveniently omitted from Sixtus's retelling of Santo Spirito's institutional history. ${ }^{81}$

Having ascertained the need for a new hospital, Sixtus then pays a visit to the members of the Santo Spirito community. In Sixtus IV Visits the Hospital Community (fig. 15), the pope occupies the center of the composition, extending his right hand in blessing. Behind him stands the papal retinue, including cardinals, footmen, two horses, and a female religious. A young acolyte holds Sixtus's opulent cope away from his body, allowing the pope to move more freely. The community of the hospital is organized into neat rows of devout supplicants (fig. 16). Closest to Sixtus are the male rectors, the institutional leadership of the hospital. They are dressed in the robes of the tertiary Order of Santo Spirito, which are emblazoned with the stemma of the hospital, the double cross of the Holy Spirit. Behind them kneels the hospital community, divided into three circumscribed categories, with rows of heads extending into the background to indicate schematically the size of the residential population. Closest to the picture plane are eight female foundlings dressed in black and red robes of different styles with white bands encircling their heads. Behind the girls are three female converse (lay hospital workers), all dressed in black, like the three men at the front of the group, but with the hoods of their robes modestly covering their heads. The artist has somewhat awkwardly made the entire stemma of the hospital visible on the robes of these women, even though, since the women stand behind the fanciulle (girls) at the front, the stemma should be partially hidden. The importance of ready visual identification of the

\footnotetext{
${ }^{79}$ MS Barb, fol. 84 ${ }^{\mathrm{v}}$ : "Animum deinde ad restituenda loca pia aedijciens hoc hospit[al]e invisit, quod vetustate p[a]ene collapsum a fundamentis instaurat."

${ }^{80}$ ASR, OSS, 1 , fol. $81^{\mathrm{v}}$, fol. $90^{\mathrm{r}}$.

${ }^{81}$ On the hospital confraternity, see De Angelis, 1950; Howe, 2000.
} 


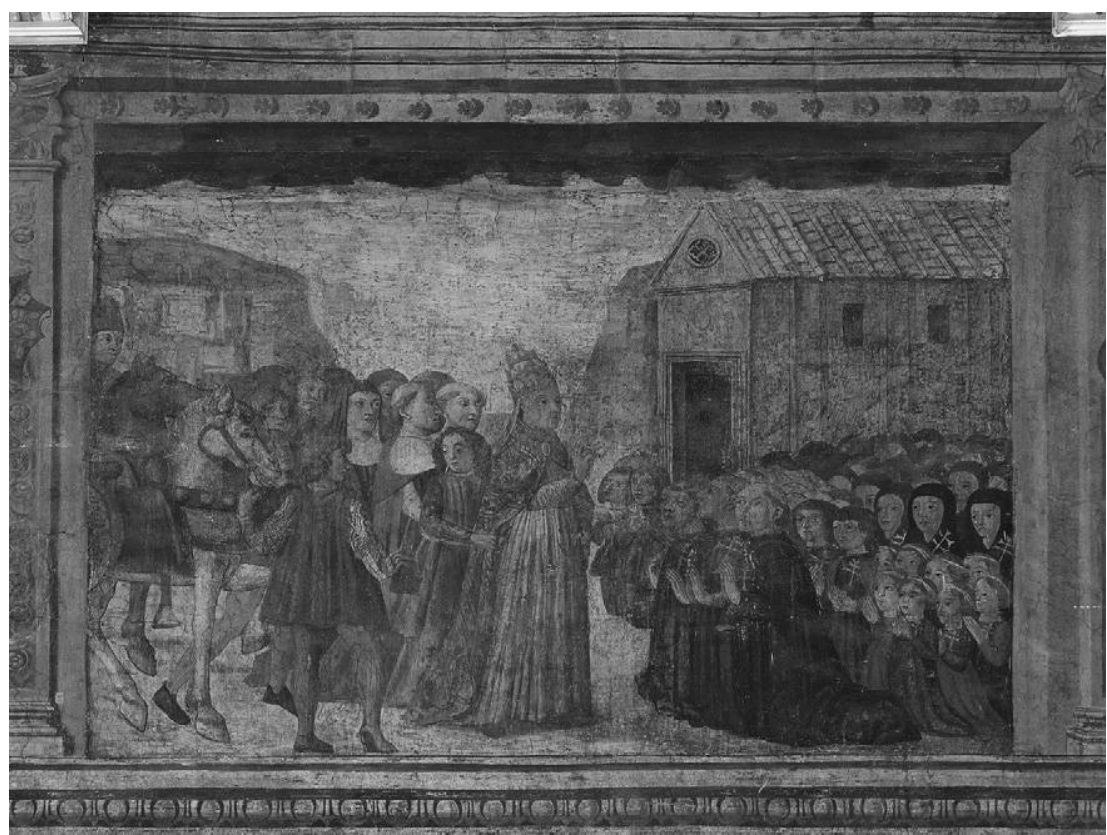

FIGURE 15. Unknown artists, Sixtus IV Visits the Hospital Community, late 1470s. South wall, Corsia Sistina, Ospedale di Santo Spirito in Sassia, Rome. Author's photograph.

hospital stemma clearly outweighed other compositional priorities, such as proportionality and foreshortening.

Although the adult male members of the hospital order are represented as the first to welcome Sixtus, the placement of the foundlings closest to the picture plane allows the viewer to see them clearly. Aside from the members of the order and the foundlings, in fact, no other members of the hospital population are distinguished. The mass of undifferentiated heads that recedes into the background constructs the rest of the community as a group that requires no further visual elaboration. The inscription below reinforces this carefully calibrated image of the hospital community, describing the scene as: "Returning again to the place, when he saw the girl and boy foundlings prostrate at his feet, moved with pity, he decided to complete this great work." 82 The foundlings are represented as pious and obedient, lending further honor to the papal action of building a more suitable home for them.

${ }^{82}$ MS Urb, fol. $13^{\text {r }}$ : "Iterum locum repetens, cum puellas, puerosq[ue] expositos, ad pedes eius prostratos vidisset, pietate motus, ad tantum opus conficiendum accenditur." 


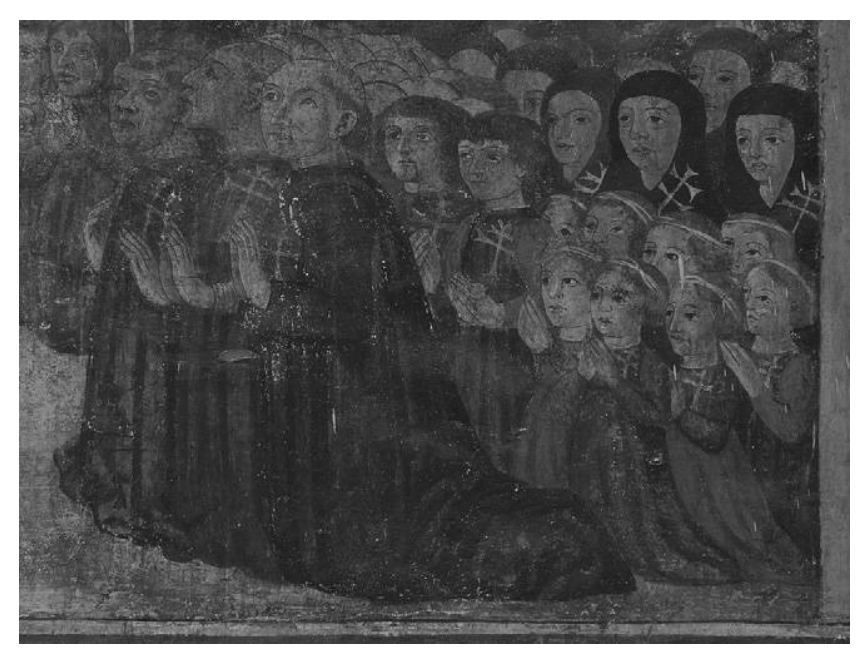

FIGURE 16. Unknown artists, Sixtus IV Visits the Hospital Community (detail), late 1470s. South wall, Corsia Sistina, Ospedale di Santo Spirito in Sassia, Rome. Author's photograph.

Importantly, this scene constructs the foundlings as the impetus for Sixtus's decision to rebuild Santo Spirito - as they were, according to the legend, for Innocent before him. His pietas reinforces the parallel between his actions and those of his illustrious predecessor: both popes recognize that the needs of abandoned children require decisive patriarchal initiative. Despite the multiple functions served by the institution as a whole, the frescoes repeatedly remind us that Santo Spirito was established for foundlings and was rebuilt for foundlings. In contrast, neither of the texts identified as sources for the Corsia Sistina inscriptions - Platina's truncated Life of Sixtus IV and Robert Flemmyng's Lucubraciunculae Tiburtinae cite abandoned children as an inspiration for the rebuilding of Santo Spirito. ${ }^{83}$ This suggests that it was the creative process of integrating the biography of Sixtus with the foundation legend in the fresco cycle that inspired the reconceptualization of Santo Spirito as a foundling hospital and the foundlings as the motivation for Sixtus's decision to rebuild it. This reinterpretation is then confirmed by Platina himself in the description of Santo Spirito as a domum expositis in the Vatican Library portrait.

\footnotetext{
${ }^{83}$ Both texts were likely written in the early 1470 s, before the rebuilding of the hospital was complete. For Platina's description, which mentions only "the poor and the sick," see Howe, 2005, 193. For Flemmyng's, see Pacifici, 28.
} 


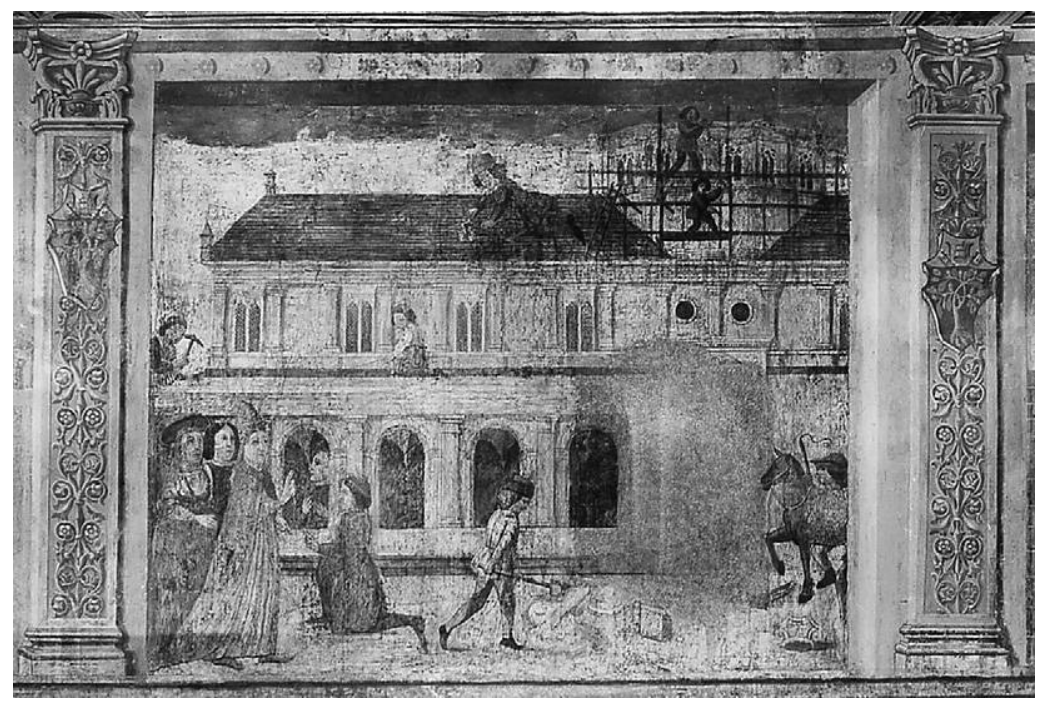

FIGURE 17. Unknown artists, Sixtus IV Rebuilds Santo Spirito, late 1470s. South wall, Corsia Sistina, Ospedale di Santo Spirito in Sassia, Rome. (C) Eunice D. Howe.

Interestingly, the foundlings that inspire Sixtus's resolve to continue with the "great work" are not the endangered infants of the Innocentine cycle, but rather the older girls and boys already resident in the hospital. Sixtus does not replicate Innocent's actions by representing his own building campaign as motivated exclusively by an immediate threat of infanticide. The time-honored role of Santo Spirito as a sanctuary for imperiled neonates is already established in the cycle by the frescoes on the east wall, whereas the Sistine scenes suggest an improvement on the Innocentine model. In the fresco, Sixtus observes the institutional workings of the hospital and perceives a need, not just for a renewal of the physical site, but also for a better system of care and accommodation for these pious older children.

The last two narrative scenes on the south wall represent the demolition of the old hospital and the building of the new one. All that remains of the first of these, also damaged by the addition of a window, is a cardinal at the left and, above, several figures dismantling the roof of the hospital plank by plank. In Sixtus IV Rebuilds Santo Spirito (fig. 17), Sixtus again enters the scene from the left with his cardinals. A reduced version of the east wing of the Corsia Sistina, seen from the north, is clearly identifiable behind him. The crossing of the ward is under construction, as we can see the scaffolding around the drum, above which the dome of the crossing will be built. The 


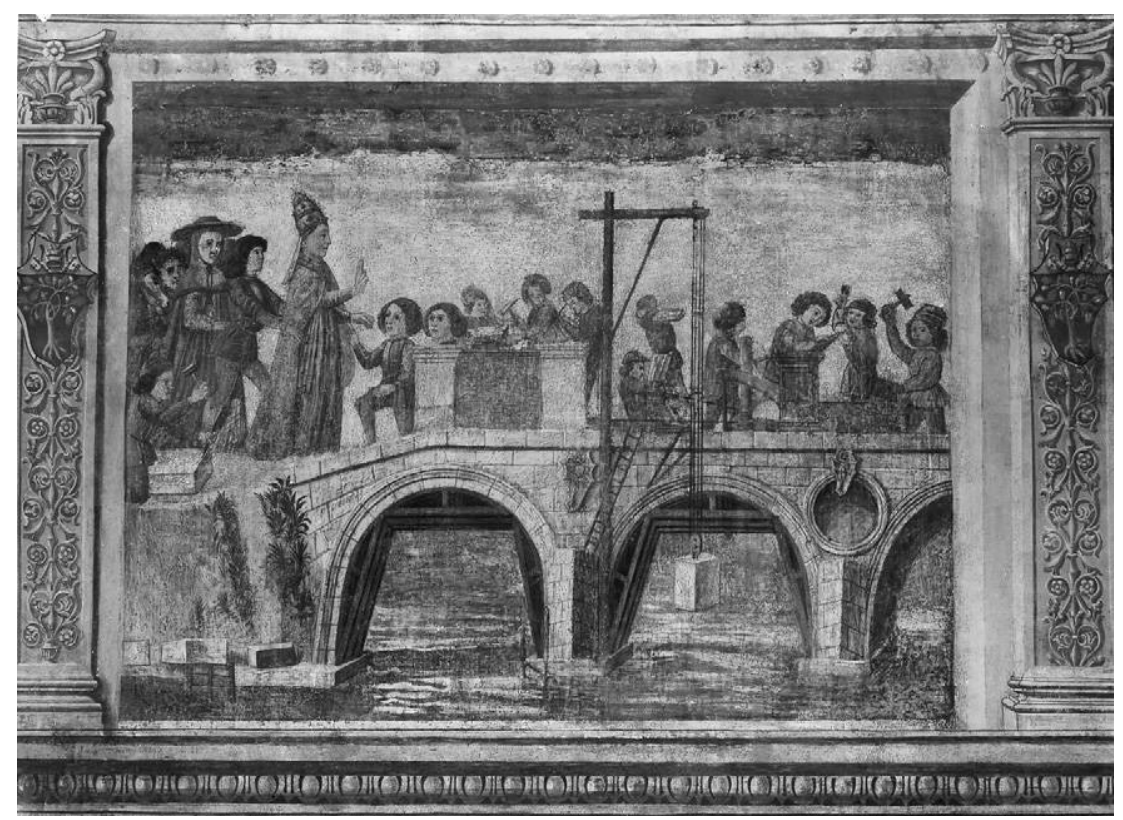

FIGURE 18. Unknown artists, Sixtus IV Rebuilds the Ponte Sisto, late 1470s. South wall, Corsia Sistina, Ospedale di Santo Spirito in Sassia, Rome. (C) Eunice D. Howe.

inclusion of the Demolition, arguably less than essential for the progression of the narrative, serves the important function of reiterating visually the ex novo status of the Sistine hospital. The scaffolding signals to us that we are viewing a working construction site, and, in the fresco in the Corsia Sistina, by virtue of his physical presence, Sixtus is an active participant in the rebuilding.

The scenes of the demolition and rebuilding of Santo Spirito follow Sixtus IV Rebuilds the Ponte Sisto (fig. 18), and the fifteenth-century inscriptions that accompanied the three scenes suggest that the two projects were to be viewed as complementary building initiatives. Like Santo Spirito, the Ponte Sisto is an example of Sistine rebuilding: the foundations of the Roman Pons Aurelius survived beneath the surface of the river and the bridge was built, literally, on the degraded remnants of the glorious imperial infrastructure. ${ }^{84}$ The inscription below the Ponte Sisto scene describes how "he rebuilt this bridge, which with reason was called

${ }^{84}$ The Aurelian bridge, also known as the Pons Valentinianus, was probably built under Emperor Caracalla ca. 215 CE. On the Ponte Sisto, see, most recently, Cardilli, 2000. 
broken, from the foundations with great care and expense for the use of the Roman people and the multitudes of pilgrims coming for the Jubilee." 85 Similarly, the inscriptions below the Demolition of the Old Hospital and Sixtus IV Rebuilds Santo Spirito emphasize both the grand scale of the enterprise and the thoroughness of the rebuilding: "In order to restore this obsolete and dirty hospital to an improved and more splendid form, [Sixtus] demolished it, right down to the foundations," and "the finest architects having been summoned from all parts, and with a great number of workmen assembled, [Sixtus] constructed the hospital itself with great diligence." ${ }^{" 86}$

Critical to an understanding of how the parallel narratives of the papal building and rebuilding of Santo Spirito figure into the larger Sistine cycle in the Corsia Sistina is the ideological importance that the concept of renovatio had in fifteenth-century Rome. Popes, particularly Sixtus, sought to portray themselves as restoring the city of Rome to its former grandeur - not building it, but rebuilding it. ${ }^{87}$ The authority of the office of the pope rested largely on the claim of Petrine succession, a central tenet of which was that the office of Vicar of Christ on earth and Bishop of Rome could be traced directly back through each legitimate pope to St. Peter himself. This rhetoric of succession permeated papal ruling strategies throughout the period under examination here and was fundamental to Sixtus's self-presentation. ${ }^{88}$

Sixtus fashioned himself as an heir, not only to Augustus and the luminaries of the Roman Empire, but also to pre-Schism popes like Innocent III. ${ }^{89}$ The Innocentine legend, already in circulation before his

${ }^{85} \mathrm{MS}$ Barb, fol. $85^{\mathrm{r}}$ : "Pontem quoq[ue] quem merito ruptum appellabant, ad utilitatem populi Romani peregrinaeq[ue] multitud[in]is ad Iubilae[u]m ventur[a]e a fundamentis mag[n]a cura et impensa restituit."

${ }^{86}$ MS Chigi, fol. 176 : "Ut aut[em] hic hospitale obsoletum et sordidu[m] in meliore[m] et splendidiorem formam redigeret totum usq[ue] ad fundame[n]ta deiecit"; MS Barb, fol. 85 multit[udin]e hosp[ital]e ipsum magno studio [a]edificat."

${ }^{87}$ On the discourse of renovatio in Rome, see, among others, Stinger. For the Carolingian context, see Krautheimer.

${ }^{88} \mathrm{On}$ the centrality of urban restoration projects to Sixtus's public image, see, most recently, Blondin.

${ }^{89}$ The scenes of Sixtus's childhood and early career, which separate the narratives of Innocent and Sixtus as builders, also place primary emphasis on his ties to the Franciscan order, even representing the pope as selected by Francis and Anthony of Padua to join the Franciscans while still in utero. The scenes of Innocent's dream and the confirmation of the Order of Santo Spirito would thus have reinforced the connection between Sixtus and the Franciscans by alluding to Innocent's dream of Francis saving the Lateran from collapse and his subsequent confirmation of the Franciscan Rule. On the Franciscan imagery in the cycle, see Cassiani; Howe, 2005, 140-46. 
pontificate, allowed the fresco cycle to frame the actions of Sixtus as reconstituting Innocent's subventions to abandoned children, an image far more powerful than one that would have presented the work of Sixtus as completely without precedent. At Santo Spirito he preserved the essential outlines of Innocent's charitable initiative, but rebuilt it completely, as three of the inscriptions emphasize, a fundamentis (from the foundations). ${ }^{90} \mathrm{By}$ simultaneously "turning his mind to the pious places" and rebuilding imperial structures, such as the Pons Aurelius, Sixtus initiated a renovatio of Rome's halcyon days during both the ancient empire and the Christian twelfth and thirteenth centuries. Sixtus also conspicuously eliminated all references to his post-Schism predecessors in the decoration of the Corsia Sistina, marking himself as the sole restorer of the Church and of the city of Rome to their past greatness.

\section{SANTO SPIRITO RENEWED}

On the south wall of the Corsia Sistina, both Sixtus and his predecessor Innocent III are represented as builders in scenes that depict the construction of the old and new hospitals of Santo Spirito. However, a tension develops in the cycle between, on the one hand, a conflation of the two popes into an idealized, but generic, personification of the office of the papacy, and, on the other, the quasi-hagiographic glorification of Sixtus the individual and the dynastic emphasis on the della Rovere family. In order to tap into the ideological power of both the foundation legend and papal renovatio, a significant portion of the fresco cycle had to be given over to the visualization of narratives in which Sixtus took no part. This obligation was in conflict, however, with the overarching goal of the cycle, which, like the Vatican Library portrait, remained the pictorial exaltation of Sixtus and of the della Rovere. This tension is evident already in the first scenes on the south wall, those following the presentation to Innocent III of the dead infants pulled from the Tiber (figs. 12 and 13).

On one level, the fresco of the Dream of Innocent III situates Innocent's decision to found Santo Spirito within a pictorial tradition that constructed dreams as motivators of ecclesiastical building. ${ }^{91}$ On another, Innocent's actions are portrayed as more passive than proactive. In the representation of the same scene in the Burgundian miniatures, Innocent is given more agency: the visit from the angel comes first, and then the fishermen, on his

\footnotetext{
${ }^{90}$ The phrase a fundamentis was also used to describe the building of the hospital in several bulls issued by Sixtus: see Howe, 2005, 101.

${ }^{91}$ See Carty.
} 
order, dredge the river for evidence of the infanticides. ${ }^{92}$ The shift between the two versions of the story deemphasizes Innocent's active engagement with the urban crisis and places the narrative stress on the visit from the angel. This change, in turn, sets the stage for the contrasting image of Pope Sixtus's decision-making process later in the Corsia cycle. Sixtus is represented as capable of a more astute analysis of his city's charitable needs, as he decides to rebuild Santo Spirito after visiting with the hospital community, assessing the requirements of its members, and concluding that their facilities were inadequate. The established medieval tradition of the visionary dream as a legitimate mode of decision-making allows us to read the representation of Innocent's actions as idealized, even adulatory. However, the Corsia Sistina version of the hospital's legendary foundation also contrasts the ways in which the respective pontiffs negotiate charitable obligations. This distinction permits a more timely laudatory reading of Sixtus's intervention at Santo Spirito, elaborating upon the image of his particular relationship to institutional charity.

The successful implementation of Sixtus's vision is depicted on the west wall in the Dedication of the Foundlings' Ward (fig. 19). As the ward was already functional at the occasion of the represented scene, the fresco can be taken as a pictorial construction of institutional life under the tutelage of Sixtus. The scene, like the Dedication of the Nobles' Ward that follows it, represents a two-storied loggiated courtyard with the entrance to one loggia labeled prominently with the inscription SIXTVS IIII FUNDAVIT. ${ }^{93}$ Sixtus enters the scene this time from the right, so that he is situated directly under the inscription. A female member of the order greets him, accompanied by a young girl. The conversa points with her left hand toward the community assembled behind her in orderly rows, a gesture Sixtus echoes with his left hand; the woman's expression is one of pious gratitude to the pope for his attentions toward the hospital. The represented hospital community comprises young boys, other converse, wet nurses, and, in the front row, the girls of the hospital. At the left, one wet nurse holds an infant while another prepares to wrap a white cloth around him. A dignified female

${ }^{92}$ In the Dijon miniatures, Innocent is also awake for his visit from the angel, which occurs while he lies sick in bed. Innocent then tells his college of cardinals what transpired with the angel, and the fishermen are dispatched to the Tiber. After the infants are presented to him, Innocent does require some additional assistance, as he seeks God's advice through prayer on the best course of action. For the inscriptions that accompanied these miniatures, see Peignot, 26-35.

${ }^{93}$ The two courtyards are all that remain of the palazzi built by Sixtus to house the foundlings and the nobles. The western courtyard preserves doors and windows framed in marble with the inscription SIXTUS IIII FUNDAVIT above each. 


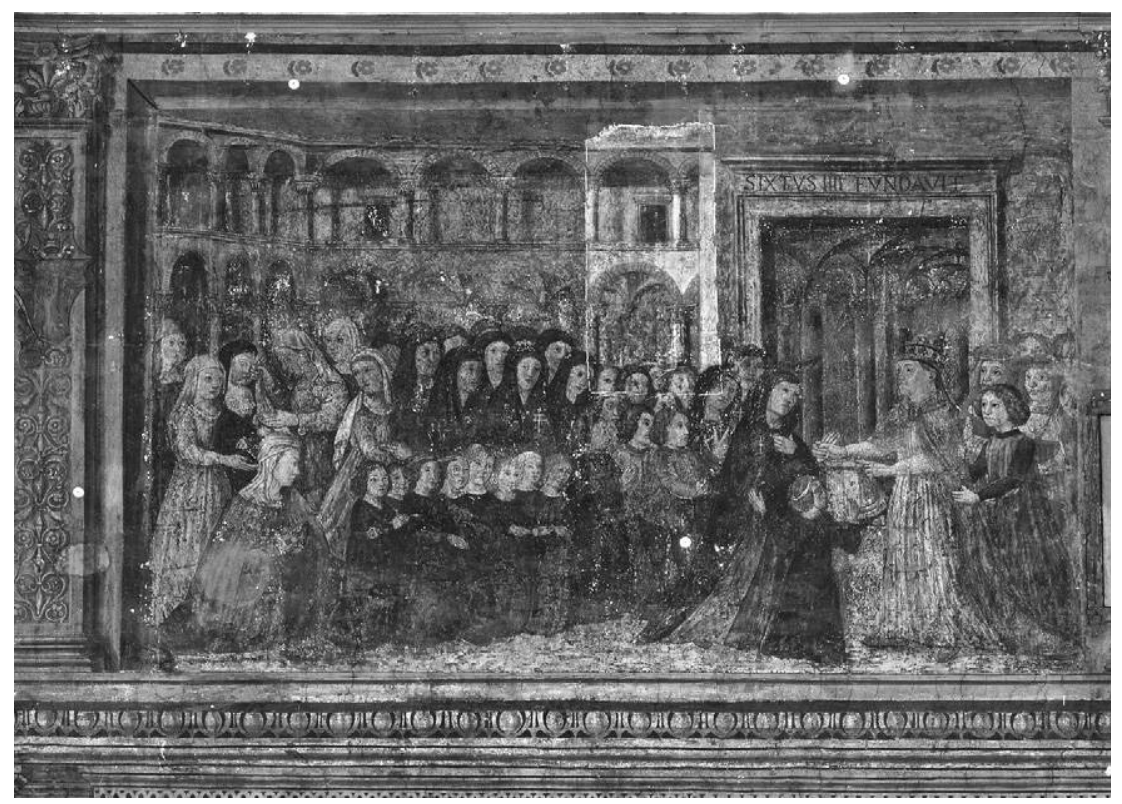

FIGURE 19. Unknown artists, Dedication of the Foundlings' Ward, late 1470s. West wall, Corsia Sistina, Ospedale di Santo Spirito in Sassia, Rome. Author's photograph.

figure, set apart but not clearly identifiable, kneels in front of the wet nurses, her attention held rapt to Sixtus and her hands joined in prayer.

The fresco's fifteenth-century inscription read: "When he saw the abandoned boys and girls prostrate at his feet with their wet nurses, he assigned them a place for living. And he mandated that the nubile girls be married with a dowry; he dedicated those more religious to the perpetual service of the foundlings. "94 A pictorial parallel is constructed between the image of Sixtus visiting the hospital community on the south wall and the image of the dedication of the newly rebuilt ward. The inscriptions originally found beneath each fresco declare that the "abandoned boys and girls" assembled "prostrate at his feet" motivate the pope to act on their behalf. However, the representations of the hospital community in the two frescoes are markedly different, articulating visually the improvements made by Sixtus to the care of foundlings at Santo Spirito. In the first fresco, the

${ }^{94} \mathrm{MS}$ Barb, fol. $85^{\mathrm{v}}$ : “Cum pueros expositos, puellasque ad pedes eius cum nutricib[us] prostrates videret locum habitandi his assignat. Mandatq[ue] puellas nubiles maritis cum dote locari: Non nulla v[er]o religiosiores servitio proiector[um] p[er]petuo dedicavit." 
community included male and female conversi as well as boy and girl foundlings. While the female converse wear the nun-like mantles also seen in the later fresco, the girl foundlings wear black-and-red dresses that closely resemble the uniforms of the boys. This intermingling of bodies and ambiguity of dress is gone in the scene of the Dedication of the Foundlings' Ward. Aside from Sixtus and his entourage of cardinals and attendants, no adult men appear in the fresco. By the same token, no women appear in the adjacent representation of life in the nobles' palace. The separation of the representation of the institutional community into two distinct scenes emphasizes that the changes ushered in by Sixtus were not exclusively visited upon the physical structure of the hospital. The pope has also inaugurated a more socially acceptable segregation of these two groups, women and nobles, both from each other and from the general population of the hospital. $^{95}$

Similarly, the girls dressed in variegated colors in the earlier fresco are outfitted in uniform black robes in the scene on the west wall, clothing that links them visually with the nun-like converse. Placed in the composition below the converse, the girls are presented as novices in training for future roles as members of the Order of Santo Spirito. In contrast to the swath of black that distinguishes the central portion of the community, the wet nurses at the left and the boys to the right stand out with their white head-coverings and pastel dresses and their multicolored clothes, respectively. The fresco articulates the order and propriety brought by Sixtus to the hospital through this standardization of dress and segregation of the hospital's internal communities.

Sixtus is presented not only as the papal patron of the institution, but also as the individual responsible for the development of a program of care for the nubile female foundlings. He dictates that they should be married with a dowry or that otherwise they should join the hospital order. The inscription implies that this was not current practice at the institution before his rebuilding of the physical site. Pictorially, Sixtus is positioned as the creative force behind this caritative program. Although he may not be in attendance for the quotidian administration of the hospital, his presence is felt, the fresco tells us, through the policies he enacted.

The idealized order of the newly rebuilt hospital's section for foundlings also contrasts vividly with the chaos of child-killing imaged on the opposite wall of the ward. The scene lies directly across the lengthy space of the Corsia Sistina from the fresco of the dead infants being presented to Pope Innocent

\footnotetext{
${ }^{95}$ On the segregation of hospital wards by sex, see Howe, 2003.
} 
III. An inverse of the diminutive corpse presented upside-down by the fisherman to Innocent, the living infant in the Dedication of the Foundlings' Ward is alert and receives the attention of multiple wet nurses. The pictorial juxtaposition of the two infants thematizes the practical impact of the hospital of Santo Spirito in the urban ambit, highlighting both the social utility of the institution and the central role of the popes as guardians of municipal welfare and communal salvation.

\section{CONCLUSION}

As in the Vatican fresco, where Sixtus IV is credited with restoring a library "hidden in squalor," so too in the frescoes and inscriptions of the Corsia Sistina cycle Sixtus is lauded for rebuilding a neglected edifice of critical social importance. In common with the visual rhetoric of foundling care elsewhere in late Quattrocento Italy, the fresco cycle at Santo Spirito underscores the central importance of the vulnerability of the infant foundling to discourses on institutional charity toward children. Through the prominent inclusion of the foundation legend of the hospital on the east wall, the mission of Santo Spirito is framed with specific reference to the protection of this special category of abandoned child, imputing to the pope the role of surrogate guardian to these potential victims of infanticide. The construction and renovatio of the hospital is presented as a generative product of papal will, with the care of foundlings situated as an integral part of the image of the pope as both Father of the Church and as restorer of past glory to the city of Rome. Serving as both a prologue for and a competitor with the Sistine scenes that dominate the ward, the Innocent III narrative presents infanticide as an urgent social problem, and positions the papal hospital of Santo Spirito as its institutional remedy. As the authority who responds to the threat of infanticide with the building of Santo Spirito, Innocent is constructed as wise judge, ideal viewer, and, most crucially, papal exemplar for Sixtus, in the subsequent frescoes depicting his life and deeds, to emulate.

The College of Wooster 


\title{
Bibliography
}

\author{
Manuscripts and Archival Sources
}

Archivio di Stato di Firenze, Provvisioni Registri 4, 19 May 1294.

Archivio di Stato di Firenze, Provvisioni Registri 174, 18 February 1484.

Archivio di Stato di Roma, Ospedale di Santo Spirito, 273, 21 January 1599.

Archivio di Stato di Roma, Ospedale di Santo Spirito, 1, seventeenth century.
Vatican City, Biblioteca Apostolica Vaticana, Barb. lat. 2040, ca. 1575-85. Cited as MS Barb.

Vatican City, Biblioteca Apostolica Vaticana, Chigi I-V-167 (n. 2205), late sixteenth century. Cited as MS Chigi.

Vatican City, Biblioteca Apostolica Vaticana, Urb. Lat. 1023, late sixteenth-early seventeenth century. Cited as MS Urb.

\section{Printed Works}

Albini, Giuliana. Città e ospedali nella Lombardia medievale. Bologna, 1993.

Atto di fondazione dell'Ospedale di Santa Maria della Misericordia in Perugia. Città di Castello, 1939.

Bianchi, Francesco. La Ca' di Dio di Padova nel Quattrocento: riforma e governo di un ospedale per l'infanzia abbandonata. Venice, 2005.

Blondin, Jill E. "Power Made Visible: Pope Sixtus IV as Urbis Restaurator in Quattrocento Rome." The Catholic Historical Review 91.1 (2005): 1-25.

Brockhaus, Heinrich. "Das Hospital Santo Spirito zu Rom im 15. Jahrhundert." Repertorium für Kunstwissenschaft 7 (1884): 281-90, 429-45.

Brown, Judith C., and Robert C. Davis, eds. Gender and Society in Renaissance Italy. London, 1998.

Burroughs, Charles. "Below the Angel: An Urbanistic Project in the Rome of Pope Nicholas V." Journal of the Warburg and Courtauld Institutes 45 (1982): 94-124.

Canezza, Alessandro. Gli arcispedali di Roma nella vita cittadina, nella storia e nell'arte. Rome, 1933.

Cardilli, Luisa. "Ponte Sisto restaurato, considerazioni in margine." In Sisto IV (2000), 434-43.
-. "La 'Corsia Lancisi' del quattrocentesco Ospedale di Santo Spirito. Studio sulla tecnica e sullo stato di conservazione della decorazione." Il Veltro. Rivista della civiltà italiana 46.1-4 (2002): 85-96.

Carty, Carolyn M. "The Role of Medieval Dream Images in Authenticating Ecclesiastical Construction." Zeitschrift fir Kunstgeschichte 62.1 (1999): 45-90.

Cassiani, Maria Alessandra. "L'Ospedale di S. Spirito in Sassia: cultura francescana e devozione nel ciclo pittorico della corsia sistina." In Sisto IV (2000), 166-73.

Chaney, Edward P. de G. "Philanthropy in Italy': English Observations on Italian Hospitals, 1545-1789." In Aspects of Poverty in Early Modern Europe, ed. Thomas Riis, 183-217. Alphen aan den Rijn, 1981.

Colonna, Flavia. L'Ospedale di Santo Spirito a Roma. Lo sviluppo dell'assistenza e le trasformazioni architettonico-funzionali. Rome, 2009.

Costa, Elda, and Laura Ponticelli. "L'iconografia del Pellegrinaio nello Spedale di Santa Maria della Scala di Siena." Iconographica 3 (2004): 110-47.

De Angelis, Pietro. L'arciconfraternita ospitaliera di Santo Spirito in Saxia. Rome, 1950. 
L'Ospedale di Santo Spirito in Saxia. 2 vols. Rome, 1960-62.

- L'architetto e gli affreschi di Santo Sprito in Saxia. Rome, 1961.

- Guido di Montpellier, Innocenzo III e la fondazione dell'Ospedale Apostolico di Santo Spirito in Santa Maria in Saxia. Rome, 1962.

Dominici, Silvia. "Un' istituzione assistenziale pubblica nella Roma dei papi: Il conservatorio delle proiette dell'Ospedale di Santo Spirito in Saxia (secoli XVI e XVII)." Rivista di Storia della Chiesa in Italia 55.1 (2001): 19-58.

Drossbach, Gisela. Christliche caritas als Rechtsinstitut: Hospital und Orden von Santo Spirito in Sassia (1198-1378). Paderborn, 2005.

. "Text und Bild im Liber Regulae des Hospitals von Santo Spirito in Sassia." In Sozialgeschichte mittelalterlicher Hospitäler, ed. Neithard Bulst and Karl-Heinz Spiess, 125-48. Ostfildern, 2007.

Esposito, Anna. “Assistenza e organizzazione sanitaria nell'Ospedale di Santo Spirito." Il Veltro. Rivista della civiltà italiana 45.5-6 (2001): 201-14.

Fanucci, Camillo. Trattato di tutte l'opere pie dell'alma città di Roma. Rome, 1601.

Florio, John. Queen Anna's New World of Words, Or Dictionarie of the Italian and English tongues. London, 1611.

Forcella, Vincenzo. Iscrizioni delle chiese e d'altri edificii di Roma dal secolo XI fino ai giorni nostri. 14 vols. Rome, 1869-84.

Gavitt, Philip. Charity and Children in Renaissance Florence: The Ospedale degli Innocenti, 1410-1536. Ann Arbor, 1990.

Guerrini, Paola. "La storia della fondazione dell'Ospedale di Santo Spirito in un manoscritto illustrato del secolo XV." Il Veltro. Rivista della civiltà italiana 45.5-6 (2001): 143-62.

Hegel, Karl, ed. Die Chroniken der oberrheinischen Städte: Strassburg. 2 vols. Leipzig, 1870-71.
Henderson, John. The Renaissance Hospital: Healing the Body and Healing the Soul. New Haven, 2006.

The holie Bible faithfully translated into English, out of the authentical Latin. Trans. English College of Douay [Gregory Martin]. Douai, 1609-10. Cited as Douay Bible.

Howe, Eunice D. The Hospital of Santo Spirito and Pope Sixtus IV. New York, 1978.

_- "Appropriating Space: Woman's Place in Confraternal Life at Santo Spirito in Sassia, Rome." In Confraternities and the Visual Arts in Renaissance Italy: Ritual, Spectacle, Image, ed. Barbara Wisch and Diane Cole Ahl, 235-58. Cambridge, 2000.

- "The Architecture of Institutionalism: Women's Space in Renaissance Hospitals." In Architecture and the Politics of Gender in Early Modern Europe, ed. Helen Hills, 63-82. Aldershot, 2003.

- Art and Culture at the Sistine Court: Platina's "Life of Sixtus IV" and the Frescoes of the Hospital of Santo Spirito. Vatican City, 2005.

Hunecke, Volker. "L'invenzione dell'assistenza agli esposti nell'Italia del Quattrocento." In "Benedetto chi ti porta, maledetto chi ti manda": L'infanzia abbandonata nel Triveneto (secoli $X V-X I X)$, ed. Casimira Grandi, 273-83. Treviso, 1997.

Kirk, Terry. "Framing St. Peter's: Urban Planning in Fascist Rome." Art Bulletin 88.4 (2006): 756-76.

Krautheimer, Richard. "The Carolingian Revival of Early Christian Architecture." Art Bulletin 24.1 (1942): 1-38.

La Cava, Angelo Francesco, ed. Liber regulae s. Spiritus (Regola dell'Ordine Ospitaliero di S. Spirito). Milan, 1947.

Lee, Egmont. Sixtus IV and Men of Letters. Rome, 1978.

Magenta, Pio. Ricerche su'le pie fondazioni e su' l'ufficio loro a sollievo dei poveri. 
Con un' Appendice sui pubblici stabilimenti di beneficenza della Città di Pavia. Pavia, 1838.

Magnuson, Torgil. "The Project of Nicholas $\mathrm{V}$ for Rebuilding the Borgo Leonino in Rome." Art Bulletin 36.2 (1954): 89-115.

Miglio, Massimo. "Una biografia pontificia per immagini. Sisto IV e l'Ospedale di Santo Spirito." Il Veltro. Rivista della civiltà italiana 45.5-6 (2001): 111-24.

Origo, Iris. The World of San Bernardino. New York, 1962.

Pacifici, Vincenzo. Un carme biografico di Sisto IV del 1477. Tivoli, 1921.

Passerini, Luigi. Storia degli stabilimenti di beneficenza e d'istruzione elementare gratuita della città di Firenze. Florence, 1853.

Peignot, Gabriel. Histoire de la fondation des hôpitaux du Saint-Esprit de Rome et de Dijon, représentée en vingt-deux sujets gravés d'après les miniatures d'un manuscrit de la bibliothèque de l'Hôpital de la Charité de Dijon, accompagnée d'une description et d'un précis chronologique. Dijon, 1838.

Presciutti, Diana Bullen. "The Visual Culture of the Foundling Hospital in Central Italy, 1400-1600.” PhD diss., University of Michigan, 2008.

_. "Carità e potere: Representing the Medici Grand Dukes as 'Fathers of the Innocenti."' Renaissance Studies 24.2 (2010): 234-59.

Ruggiero, Guido. The Boundaries of Eros: Sex Crime and Sexuality in Renaissance Venice. New York, 1985.

Sandri, Lucia. L'Ospedale di S. Maria della Scala di S. Gimignano nel Quattrocento: Contributo alla storia dellinfanzia abbandonata. Florence, 1982.

Schiavoni, Claudio. "Gli infanti 'esposti' del Santo Spirito in Saxia di Roma tra '500 e '800: Numero, ricevimento, allevamento e destino." In Enfance abandonnée et société en Europe $X I V^{e}-X X^{e}$ siècle, ed. Società italiana di demografia storica, 1017-64. Rome, 1991.

Sisto IV: le arti a Roma nel primo Rinascimento. Ed. Fabio Benzi. Rome, 2000.

Stinger, Charles L. "The Campidoglio as the Locus of Renovatio Imperii in Renaissance Rome." In Art and Politics in Late Medieval and Early Renaissance Italy: 1250-1500, ed. Charles M. Rosenberg, 135-56. Notre Dame, 1990.

Surdacki, Marian. Il brefotrofio dell'ospedale di Santo Spirito in Roma nel XVIII secolo. Warsaw, 2002.

Takahashi, Tomoko. Il Rinascimento dei trovatelli: Il brefotrofio, la città e le campagne nella Toscana del XV secolo. Rome, 2003.

Trexler, Richard C. "Infanticide in Florence: New Sources and First Results." History of Childhood Quarterly 1 (1974): 98-116.

Walter, Ingeborg. "Die Sage der Gründung von Santo Spirito in Rom und das Problem des Kindesmordes." Mélanges de l'École française de Rome 97.2 (1985): 819-79.

-. "Aussetzung und Kindestötung in den Gründungslegenden einiger italienischer Spitäler." In Armut und Armenfürsorge in der italienischen Stadtkultur zwischen 13. und 16. Jahrhundert: Bilder, Texte und soziale Praktiken, ed. Philine Helas and Gerhard Wolf, 163-74. Frankfurt am Main, 2006.

Westfall, Carroll William. In This Most Perfect Paradise: Alberti, Nicholas V, and the Invention of Conscious Urban Planning in Rome, 1447-55. University Park, PA, 1974. 